\title{
STUDIUL FAUNEI DIN EPOCA ROMANĂ DE LA OSTROV, PUNCTUL FERMA 4, JUD. CONSTANȚA (DUROSTORUM)
}

\author{
ADRIAN BĀLĀȘESCU, VALENTIN RADU
}

\begin{abstract}
ETUDE DE LA FAUNE D'EPOQUE ROMAINE D'OSTROV, POINT FERMA 4, DEPARTEMENT CONSTANTTA (DUROSTORUM)
\end{abstract}

L'étude de la faune issue du site romain Ostrov (Durostorum) indique que l'élevage était prépondérant. Les bovins dominent le spectre de faune, que l'on considère le nombre de restes ou le nombre d'individus; ils sont suivis par les caprinés et le porc. Le cheval était également consommé.

L'analyse des âges d'abattage pour les principales espèces montre que les bovins et les caprinés étaient élevés principalement pour les produits secondaires, lait, laine et force (bovins), leur viande étant également recherchée. Concernant le porc, le profil d'abattage suggère que la plupart des individus ont été abattus entre un an et deux ans, c'est-à-dire lorsque l'animal atteint son poids maximal.

Si l'on compare cet établissement avec d'autres sites contemporains du sud-est de la Roumanie, Durostorum s'inscrit dans les tendances générales de l'époque : l'élevage prédomine, les bovins étant la principale espèce domestique, et la chasse est sporadique.

L'étude de ce premier lot de faune de Durostorum est très importante pour la période romaine des $\mathrm{II}^{\mathrm{e}}$ et III ${ }^{\mathrm{e}}$ siècles après J.-C. car il s'agit de la seule étude réalisée pour le sud de la région de Dobrogea.

MOTS-CLES: archéozoologie, époque romaine, Ostrov (Durostorum), élevage, chasse CUVINTE CHEIE: arheozoologie, epoca romană, Ostrov (Durostorum), creşterea animalelor, vânătoare

\section{INTRODUCERE}

Situl de la Ostrov, punctul Ferma 4 (cod RAN 62547.01) se găseşte aproximativ în dreptul bomei kilometrice 132.100 a drumului naţional DN3A Bucureşti-Constanţa. Investigațiile arheologice din acest sit au fost realizate începând cu anul 1955, prin intervenții de salvare și din anul 1997 până în prezent, prin cercetări arheologice sistematice ${ }^{1}$. În stadiul actual al cercetării, indiferent de statutul așezării romane de aici ${ }^{2}$, se poate afirma că aceasta este strâns legată de castrul legiunii XI Claudia cantonată la Durostorum, ce se află la circa $3,5 \mathrm{~km}$ vest.

Resturile faunistice care fac obiectul acestui articol provin din săpăturile arheologice efectuate de către Crişan Muşeţeanu şi Dan Elefterescu, între anii 1997-1998, din complexe arheologice de pe malul Dunării, mai exact din șapte gropi menajere dintre cele 80 descoperite până în prezent.

Analize arheozoologice efectuate pe materiale prelevate din aşezările romane, niveluri databile în secolele II-III p. Chr., din Dobrogea sunt extrem de rare ${ }^{3}$. Una dintre caracteristicile acestor analize este faptul că eşantioanele studiate sunt foarte reduse din punct de vedere numeric (sub 420 de resturi). Comparativ cu acestea, eşantionul studiat pentru situl de la Ostrov (Durostorum) este aproape de trei ori mai mare, rezultatele analizelor arheozoologice având posibilitatea de a surprinde mult mai bine paleoeconomia animalieră din această perioadă. Eşantioane asemănătoare din punct de vedere numeric, cu cel din prezentul studiu, sunt cele de la Barboşi ${ }^{4}$ (jud. Galaţi) şi Stolniceni ${ }^{5}$ (jud. Vâlcea), situate în stânga Dunării.

\footnotetext{
${ }^{1}$ Culică 1978, 113; Muşeţeanu 2003; Damian, Bâltâc 2008; vezi şi rapoartele din CCA 1998-2013 http://cronica.cimec.ro/

2 Despre problematica aşezării de la Ostrov, vezi, în acest volum, articolul A. Bâltâc, I. Paraschiv-Grigore, p. $155-163$.

${ }^{3}$ Haimovici 1996; Haimovici 2003; Stanc 2009; Stanc, Bejenaru 2009

${ }^{4}$ Haimovicil 983

${ }^{5}$ Udrescu 1979
} 


\section{METODOLOGIE}

Specificăm că tipul de prelevare al materialului faunistic a fost făcut direct - „la ochi” - ceea ce prezintă o serie de avantaje şi dezavantaje, fapt care a mai fost adus în discuție şi cu altă ocazie ${ }^{6}$.

Fauna relativ bogată aparţine atât nevertebratelor (scoici), cât şi vertebratelor, în special mamiferelor, acestea din urmă fiind predominante. Determinările anatomice şi taxonomice au fost realizate cu ajutorul colecţiilor osteologice de referinţă ale Laboratorului de Arheozoologie, din cadrul Centrului Naţional de Cercetări Pluridisciplinare, Muzeul Naţional de Istorie a României. De asemenea, au fost consultate lucrările metodologice ale lui Barone ${ }^{7}$ şi Schmid $^{8}$ pentru mamifere. Deosebirea dintre oaie şi capră a fost făcută pe baza scheletul post-cranian după criteriile lui Boessneck, Muller și Teichert ${ }^{9}$ testate de Clutton-Brock et alii $^{10}$ şi de Prummel şi Frisch ${ }^{11}$; pentru resturile dentare, am utilizat lucrările lui Payne ${ }^{12}$, Helmer ${ }^{13}$, Hallstead et alii ${ }^{14}$, precum şi Balasse şi Ambrose $^{15}$.

Vârstele de abataj (de sacrificare) au fost estimate după erupţile dentare cu ajutorul lucrării lui Schmid ${ }^{16}$, iar pentru uzurile dentare am apelat la lucrările lui Ducos ${ }^{17}$ şi Grant ${ }^{18}$ pentru bovine, Payne ${ }^{19}$ şi Helmer ${ }^{20}$ pentru ovicaprine şi Horard-Herbin ${ }^{21}$ pentru suine.

Corelarea datelor biologice cu cele zootehnice s-a realizat după Forest ${ }^{22}$.

Măsurătorile resturilor faunistice au fost realizate cu un şubler care prezintă o precizie

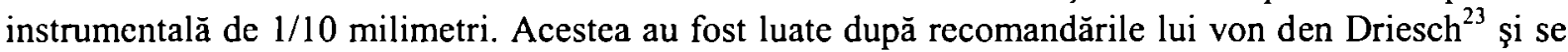
regăsesc în anexa cu date de biometrie (anexa 2). Cu toată imprecizia metodei de estimare a taliei (înălţimii la greabăn) datorată puternicelor allometrii în special la animalele domestice, aceasta a fost realizată utilizând coeficientiii reuniţi de către von den Driesch şi Boessneck ${ }^{24}$, respectiv de către Udrescu, Bejenaru și Hrişcu ${ }^{25}$.

\section{PREZENTAREA MATERIALULUI FAUNISTIC PE COMPLEXE ARHEOLOGICE}

Materialul faunistic studiat $(\mathrm{NR}=1134)$ a fost prelevat din complexe arheologice de tipul gropilor, notate de către arheologi în ordinea descoperirii, cu siglele: $g_{30}, g_{32}, g_{33}, g_{34}, g_{40}, g_{41}, g_{42}(740$ fragmente resturi determinate) şi din nivelul de cultură roman (394), datat în secolele II-III p. Chr. Aceste complexe se găsesc în zona marginală a sitului, utilizată din timp în timp pentru a extrage argila şi reutilizată simultan ca zonă de deşeuri menajere ${ }^{26}$.

S-au identificat resturi de nevertebrate (scoici - într-un număr redus, doar cinci resturi de Unio sp. în $\mathrm{g}_{33}$ ) şi vertebrate (păsări şi mamifere). Resturile de păsări (şapte) sunt exclusiv de găină (Gallus domesticus) şi au fost descoperite numai în nivelul de cultură.

Din cele 1122 de fragmente osteologice atribuite mamiferelor, s-au determinat specific 988 $(88,05 \%)$. Toate aceste fragmente osoase prezintă caracteristicile unor resturi menajere, fapt susţinut şi

6 Popovici et alii 2002, 57-58

${ }^{7}$ Barone 1986

8 Schmid 1972

9 Boessneck, Muller, Teichert 1964

${ }^{10}$ Clutton-Brock et alii 1990

11 Prummel, Frisch 1986

12 Payne 1985

${ }^{13}$ Helmer 2000

${ }^{14}$ Hallstead et alii 2003

${ }^{15}$ Balasse, Ambrose 2005

${ }^{16}$ Sclimid 1972

${ }^{17}$ Ducos 1968

${ }^{18}$ Grant 1982

${ }^{19}$ Payne 1973

${ }^{20}$ Helmer 2000

${ }^{21}$ Horard-Herbin 1997

22 Forest 1997

${ }^{23}$ von den Driesch 1976

${ }^{24}$ von den Driesch, Boessneck 1974

${ }^{25}$ Udrescu, Bejenaru, Hrişcu 1999

${ }^{26}$ Elcfterescu 2011, 115 
de procentul mare $(65,26 \%)$ prelevat din gropi. De asemenea, majoritatea resturilor de mamifere prezintă pe suprafaţa lor urme de tăiere (PI. I), unele mai fine (de descărnare), altele mai grosolane (de dezarticulare şi de spargere a diafizei osului pentru extragerea măduvei osoase), precum și foarte rare urme de ardere (PI. II/5).

Cantitatea de material prelevat din gropi variază extrem de mult: trei și patru resturi în $\mathrm{g}_{30}$ şi $\mathrm{g}_{42}, 27$ de resturi în $\mathrm{g}_{34}, 29$ de resturi în $\mathrm{g}_{40}, 55$ de resturi în $\mathrm{g}_{41}, 85$ de resturi în $\mathrm{g}_{32}, 537$ (47,35\% din tot materialul faunistic) în $\mathrm{g}_{33}$. Direct proporţional cu cantitatea de material osteologic prelevat din aceste complexe este şi numărul de specii identificate şi numărul minim de indivizi prezumați. Astfel, dacă în $g_{30}$ şi $g_{42}$ s-au identificat două specii şi doi indivizi, în $g_{33}$ s-au identificat 10 specii şi 41 de indivizi (vezi figura 1).

Analiza materialului a dus la identificarea a zece specii de mamifere, dintre care şase sunt domestice: cal (Equus caballus), vită (Bos taurus), oaie (Ovis aries), capră (Capra hircus), porc (Sus domesticus) şi câine (Canis familiaris) şi patru sălbatice: cerb (Cervus elaphus), căprior (Capreolus capreolus), mistreț (Sus scrofa) şi bursuc (Meles meles) (PI. I; II).

\begin{tabular}{|c|c|c|c|c|c|c|c|c|c|c|c|c|c|c|c|c|c|c|c|c|c|}
\hline \multirow[b]{2}{*}{ Specii } & \multirow{2}{*}{$\begin{array}{l}\mathrm{nc} \\
\mathrm{NF} \\
\end{array}$} & \multicolumn{2}{|c|}{$\mathrm{g} 30$} & \multicolumn{2}{|c|}{$\mathrm{g} 32$} & \multicolumn{2}{|c|}{ g33 } & \multicolumn{2}{|c|}{ g34 } & \multicolumn{2}{|c|}{$\mathrm{g} 40$} & \multicolumn{2}{|c|}{ g41 } & \multicolumn{2}{|c|}{$\mathrm{g} 42$} & \multicolumn{2}{|c|}{ Total } & \multicolumn{2}{|l|}{ Total } & \multicolumn{2}{|c|}{ domestic/sălbati } \\
\hline & & NF & NMI & $\mathrm{NF}$ & NMI & $\mathrm{NF}$ & NMI & $\mathrm{NF}$ & NMI & $\mathrm{NF}$ & NMI & $\mathrm{NF}$ & NMI & $\mathrm{NF}$ & NMI & NF & $\%$ & NMI & $\%$ & $\mathrm{NF} \%$ & NMI\% \\
\hline Equus caballus & 5 & & & 9 & 2 & 4 & 1 & & & & & 2 & 1 & 1 & 1 & 21 & 2,13 & 5 & 6,67 & & \\
\hline \begin{tabular}{|l|} 
Bos taurus \\
\end{tabular} & 247 & 2 & 1 & 40 & 3 & 334 & 15 & 13 & 2 & 21 & 2 & 37 & 2 & 2 & 1 & 696 & 70,45 & 26 & 34,67 & & \\
\hline \begin{tabular}{|l|} 
Ovis/Capra \\
\end{tabular} & 33 & 1 & 1 & 12 & $\mathrm{I}$ & 35 & 8 & 1 & $T$ & 2 & 1 & 2 & 2 & & & 86 & 8,70 & 14 & 18,67 & & \\
\hline \begin{tabular}{|l|} 
Ovis aries \\
\end{tabular} & 6 & & & & & 9 & 2 & & & & & & & & & 15 & 1,52 & 2 & 2,67 & 99,19 & \begin{tabular}{|l|}
94,67 \\
\end{tabular} \\
\hline Capra hircus & $\frac{12}{12}$ & & & 2 & $T$ & 10 & 3 & $\overline{3}$ & $T$ & & & & & & & 27 & 2,73 & 5 & 6,67 & & \\
\hline Sus domesticus & 38 & & & 7 & 2 & 60 & 8 & $\overline{2}$ & $T$ & 2 & 1 & 3 & 3 & & & 112 & 11,34 & 15 & 20,00 & & \\
\hline Canis familiaris & 15 & & & $\overline{5}$ & $\frac{2}{2}$ & 2 & 1 & $T$ & $T$ & & & & & & & 23 & 2,33 & 4 & 5,33 & & \\
\hline Cervus elaphus & 1 & & & & & 3 & 1 & & & & & & & & & 4 & 0,40 & 1 & 1,33 & & \\
\hline \begin{tabular}{|l} 
Capreolus capreolus \\
\end{tabular} & & & & & & 1 & 1 & & & & & & & & & $T$ & 0,10 & 1 & 1,33 & & \\
\hline \begin{tabular}{|l|} 
Sus scrofa \\
\end{tabular} & & & & & & 1 & $\mathrm{I}$ & & & & & & & & & 1 & 0,10 & 1 & 1,33 & 0.81 & 5,33 \\
\hline Meles meles & & & & & & & & 2 & 1 & & & & & & & 2 & 0,20 & 1 & 1,33 & & \\
\hline Total mamifere determinate & 357 & 3 & 2 & 75 & $\pi$ & 459 & 41 & 22 & 7 & 25 & 4 & 44 & 8 & 3 & 2 & 988 & 100,00 & 75 & 100,0 & 100,0 & 100,0 \\
\hline Indet mamifere & 30 & & & 10 & & 73 & & 5 & & 4 & & $\pi$ & & 1 & & 134 & & & & & \\
\hline Total mamifere & 387 & 3 & & 85 & & 532 & & 27 & & 29 & & 55 & & 4 & & 1122 & & & & & \\
\hline \begin{tabular}{|l|} 
Unio sp. \\
\end{tabular} & & & & & & 5 & & & & & & & & & & 5 & & & & & \\
\hline \begin{tabular}{|l} 
Gallus domesticus \\
\end{tabular} & 7 & & & & & & & & & & & & & & & 7 & & & & & \\
\hline \begin{tabular}{|l|} 
Total fauna \\
\end{tabular} & 394 & 3 & & 85 & & 537 & & 27 & & 29 & & 55 & & 4 & & 1134 & & & & & \\
\hline
\end{tabular}

FIGURA 1. Repartiția numerică și procentuală a resturilor de faună descoperite în nivelul cultural (nc) şi în complexele arheologice (gropi) de la Ostrov (Durostorum)

În complexul arheologic $\mathrm{g}_{30}$ s-au identificat trei resturi, din care două aparţin unui individ adult de Bos taurus şi unul atestă o ovicaprină adultă.

Complexul $g_{32}$ a furnizat 75 de resturi $(7,59 \%)$ ce aparţin unui număr de cinci specii, toate domestice. Calul (Equus caballus) a fost identificat pe baza a nouă resturi osteologice ce provin de la doi indivizi adulţi maturi, care au fost evidenţiaţi pe două resturi de mandibulă stângă, dintre care unul este mascul (prezintă canini). Vita (Bos taurus) prezintă cel mai mare număr de resturi din cadrul complexului (40). Acestea aparţin unui număr de trei indivizi: un nou născut identificat pe baza unui metapod şi doi indivizi subadulți/adulţi de peste $2-2 \frac{1}{2}$ ani determinaţi pe baza a două metacarpiene distale stânga epifizate. Ovicaprinele (12 resturi cărora nu li s-a putut da o diagnoză specifică) sunt reprezentate printr-un individ adult în vârstă de peste $3 \frac{1}{2} 2$ ani (ulnă stânga epifizată distal). S-au identificat până la nivel de specie şi două resturi de capră: un corn de tip săbiat şi o extremitate distală de metacarp care au aparţinut unui individ adult, mascul. Porcul domestic este prezent prin doi indivizi cărora le aparțin şapte resturi osoase. Cei doi indivizi sunt un infans, identificat pe baza unui metacarp III şi un juvenil de 14-16 luni, determinat pe baza dentiţiei superioare. Câinelui (Canis familiaris) îi aparţin doi indivizi: un juvenil ${ }^{27}$ sub 6 luni, identificat pe baza unui schelet aproape complet (prezintă numai oasele lungi: două humerusuri, o ulnă - stânga, două coxale, două femure, două tibii) și un individ adult de peste 18 luni.

Din complexul arheologic $\mathrm{g}_{33} \mathrm{~s}$-a prelevat cea mai mare cantitate de material osteologic, dintre care 459 de resturi au fost determinate specific. Acestea au provenit de la 41 de indivizi $(38,68 \%)$ ce aparţin unui număr de nouă specii (șase domestice şi trei sălbatice). Cabalinelor le aparțin patru resturi atribuite unui individ adult. Vitei domestice îi aparţin un număr de 334 de fragmente osteologice ce sunt atestate un număr de 15 indivizi prezumaţi. Aceştia au următoarele vârste: un infans determinat

\footnotetext{
${ }^{27}$ În cadrul statisticii din fig. 1, acest individ juvenil de Canis familiaris este considerat ca un singur rest osteologic.
} 
pe un metatars proximal dreapta foarte poros, doi juvenili identificaţi pe baza a două metatarsiene dreapta neepifizate distal cu dimensiuni foarte mici, 12 subadulţi/adulţ̧i determinaţi pe 12 metacarpiene stânga epifizate distal (peste 2-21/2). În acest grup al subadulților/adulţilor există şi indivizi de peste $3 \frac{1}{2}-4$ ani (cel puțin patru indivizi identificaţi pe baza a patru humerusuri dreapta epifizate proximal şi patru femure dreapta epifizate proximal) sau chiar în vârstă de 6-8 ani (o mandibulă stânga). Remarcăm prezența unui craniu acomut de vită (PI. I/1). Astfel de resturi s-au mai descoperit doar în așezarea civilă de la Barboși ${ }^{28}$. Ovicaprinele prezintă un număr redus de resturi (35) ce au aparţinut unui număr de opt indivizi toţi determinaţi pe baza erupţiei şi uzurii dentare. S-au identificat: un infans de 2-6 luni şi doi juvenili între 9-12 luni, un subadult de 2-3 ani, trei adulţi între 4-6 ani și un adult între 6-8 ani (PI. II/4). Pe lângă resturile de ovicaprine (denumite astfel generic), sau mai pus în evidență şi fragmente osteologice atribuite specific speciilor Ovis aries (nouă) şi Capra hircus (10). Resturile de oaie aparțin a doi indivizi subadulți/adulţi de peste $1 \frac{1}{2}$ an determinaţi prin intermediul a două tibii dreapta distal epifizate. Capra este reprezentată de trei indivizi: un juvenil (diafiză de radius) şi doi subadulți/adulţi certificaţi de două metatarsiene întregi de pe partea stângă. Resturile de porc domestic, care sunt în număr de 60 , au permis identificarea a opt indivizi, majoritatea fiind determinaţi pe baza dentiţiei (erupţie şi uzură dentară). Astfel, s-au identificat: un infans de circa 4-6 luni ${ }^{29}$ (prezintă mai multe resturi ce provin din partea anterioară a corpului: două scapule, două humerusuri, două radiusuri, două ulne, şapte metacarpiene, 12 coaste), doi juvenili din care unul de 8-9 luni şi altul de 14-16 luni şi cinci sub-adulţi: trei de 18-20 luni, unul de 18-22 luni şi unul de 24 luni (PI. II/5-6). Cele douã fragmente osteologice de câine descoperite aparţin unui individ adult.

Vânatul este reprezentat de un număr redus de resturi osoase ce aparţin următoarelor specii: cerb (trei), căprior (unul) şi mistreţ (unul). Cerbul (Cervus elaphus) este reprezentat prin două resturi de corn şi o scapulă epifizată ale unui subdult/adult. Căpriorul (Capreolus capreolus) a fost identificat pe baza unui corn pe peduncul. Acesta provenea de la un mascul care a fost vânat între lunile martieoctombrie $^{30}$. Mistreţul (Sus scrofa) a fost determinat pe baza unui canin inferior ce a aparţinut unui individ adult mascul de circa $2-3$ ani.

Din complexul $\mathrm{g}_{34} \mathrm{~s}$-au determinat 22 de resturi osteologice, ce au fost atribuite unui număr de cinci specii (patru domestice şi una sălbatică). Speciei Bos taurus îi aparţin 13 fragmente, ce provin de la doi indivizi subadulți/adulţi determinaţi pe baza a două extremităţi de metatarsiene epifizate distal. S-a mai identificat şi un rest de ovicaprin (maxilar) ce aparţine unui individ subadult. Resturile de capră sunt în număr de trei şi aparţin unui individ subadult/adult cu vârsta de peste 1 an şi 8 luni determinat pe baza unei extremităţii distale de tibie. Acesta avea coarnele de tip săbiat (PI. II/3). Porcul este prezent prin două resturi osoase atribuite unui individ juvenil de circa 1 an, determinat pe baza dentiţiei superioare. Câinele a fost identificat pe baza unui rest de maxilar ce aparţine unui individ adult. Vânatul este reprezentat de douã resturi osoase (un radius şi o tibie) atribuite unui bursuc (Meles meles) juvenil (PI. II/7).

Complexul arhcologic $\mathrm{g}_{40}$ a furnizat 25 de fragmente osoase determinate, care sunt atribuite unui număr de trei specii de mamifere domestice. Bovinele au cea mai mare pondere în cadrul complexului, fiind identificate 21 de resturi ce aparţin unui număr de doi indivizi adulţi de peste $3 \frac{1}{2}-4$ ani determinaţi pe baza a două extremităł̧i de femur proximal epifizate (unul din indivizi are o vârstă între 4-6 ani, pe baza uzurii dentare). Cele două resturi de ovicaprin descoperite sunt atribuite unui individ adult. Porcul domestic este prezent prin două fragmente osteologice ce aparţin unui individ subadult de circa 18-20 luni, determinat pe baza unui rest de mandibulă dreapta.

În complexul $\mathrm{g}_{41} \mathrm{~s}$-au identificat 44 de resturi osoase, din care două aparţin speciei Equus caballus, provenind de la un individ de peste 2 ani determinat pe baza unei extremităţii distale epifizate de tibie stânga. Vita domestică ( 37 de fragmente osoase) este reprezentată de doi indivizi adulţi: unul de 3-4 ani şi altul de circa 10 ani determinaţi pe baza uzurii dentare a două resturi mandibulare. Prin două fragmente osoase sunt reprezentate şi ovicaprinele, care prezintă următoarele vârste de sacrificare: un juvenil identificat printr-un rest diafizar de tibie şi un adult bătrân de circa 8-

\footnotetext{
${ }^{28}$ Haimovici 1983

${ }^{29}$ În cadrul statisticii din fig. 1, acest individ juvenil de Sus domesticus este considerat un singur rest osteologic.

${ }^{30}$ Schmid 1972, 90
} 
10 ani determinat pe baza unei mandibule. Cele 3 fragmente mandibulare stânga atribuite porcului domestic, aparţin unui număr de trei indivizi ale căror vârste de sacrificare au fost determinate pe baza erupţiei şi uzurii dentare. Astfel s-au identificat un infans de 4-6 luni și doi juvenili unul de 14-16 luni şi altul de 16-18 luni.

Din complexul $\mathrm{g}_{42} \mathrm{~S}$-au prelevat trei resturi osoase care sunt atribuite calului şi vitei domestice. Printr-un metatars întreg s-a identificat un individ de cal. Cele două resturi atribuite vitei domestice aparţin unui individ juvenil/subadult determinat pe baza unei extremităţi proximale de radius stânga.

Din nivelul cultural (secolele II-III p. Chr.) provin 357 resturi determinate specific care reprezintă $36,1 \%$ din totalul faunei. În cadrul studiului nostru pentru a evita o suprareprezentare a numărului minim de indivizi (NMI), noi nu am mai estimat acest parametru de cuantificare şi pentru nivelul cultural.

Repartiţia resturilor osoase de mamifere pe elemente anatomice se regăseşte în anexa 1 .

\section{CARACTERISTICI ALE PALEOECONOMIEI ANIMALIERE}

Numărul mare de resturi (NR) şi de indivizi prezumaţi (NMI) atribuiţi mamiferelor domestice demonstrează că activitatea de creştere a animalelor juca un rol important în cadrul comunităţii umane de la Ostrov (Durostorum). Astfel, se observă că bovinele au cea mai mare pondere $(70,4 \%$ NR şi 33\% NMI), urmate de ovicaprine (13\% NR și $28 \%$ NMI) şi porcine (11,3\% NR și $20 \%$ NMI) (fig. 2). Pe lângă aceste specii nu trebuie să omitem şi valoarea nutriţională a calului, a cărui carne era consumată de asemenea. Dovadă sunt resturile osteologice care prezintă urme grosiere de tăiere (trei din 21), provenite de la un topor: o vertebră cervicală tăiată transversal, o tibie şi un metapod secționat la nivelul diafizei.

Vânătoarea avea un caracter secundar, rolul său fiind neglijabil, având în vedere că vânatul este slab reprezentat ca număr de specii (patru), număr de fragmente $(0,8 \%)$ şi număr minim de indivizi $(5,3 \%)$.

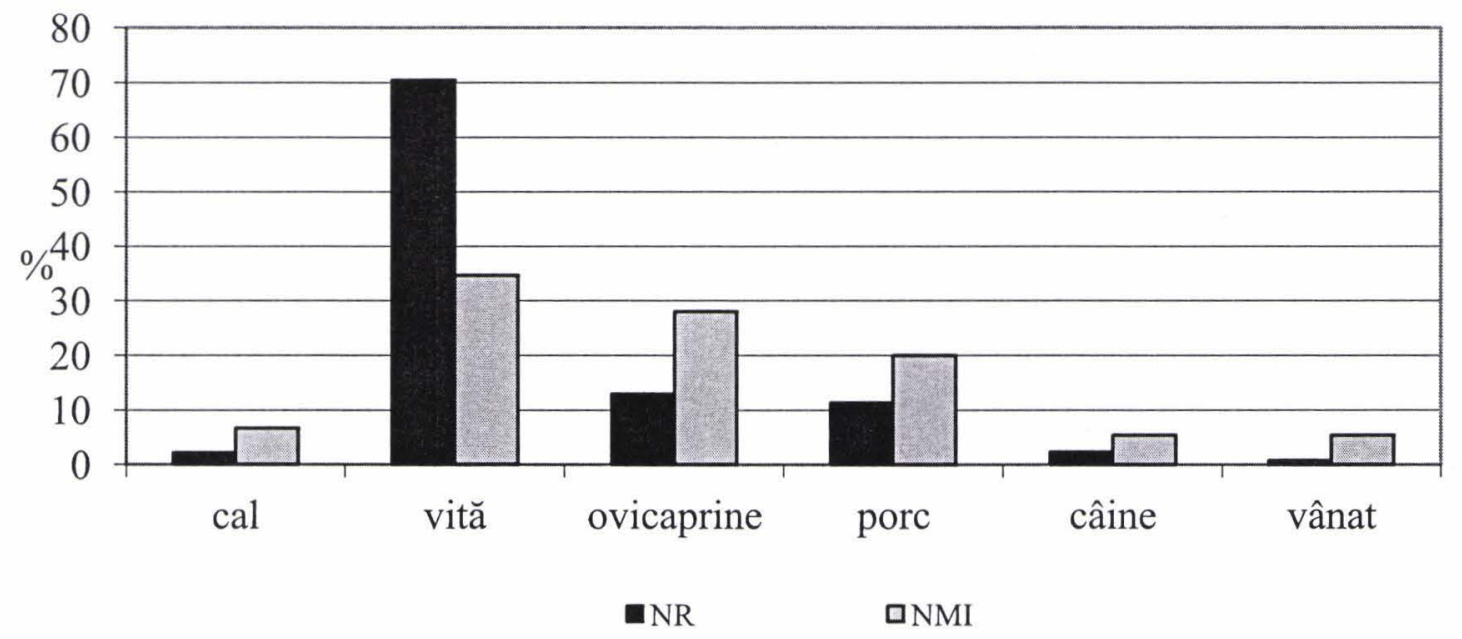

FIGURA 2. Distribuţia pe specii de mamifere a resturilor faunistice (NR) şi a numărului minim de indivizi (NMI)

Vârstele de sacrificare ale principalelor specii domestice ne arată raţiunile pentru care acestea erau crescute în timpul vieţii lor până în momentul în care erau tăiate pentru consum. Astfel, la bovine observăm că peste $50 \%$ dintre indivizi sunt adulţi ceea ce ar sugera creșterea lor pentru producţia de lapte (produse lactate), un număr foarte mic dintre animale fiind utilizate şi pentru tracţiune. Indivizii juvenili (între 6 luni şi 2 ani) ar sugera producţia de carne fragedă, în timp ce subadulţii (între 2 ani şi $31 \frac{1}{2}$ ani) erau crescuţi pentru carne până în momentul când atingeau o greutate maximă ce permitea obţinerea unui randament mare la tăiere (fig. 3).

Ovicaprinele erau de asemenea crescute pentru produsele lor secundare (lapte şi lână) dovadă stând numărul mare de animale subadulte (de peste 2 ani), adulte şi mature (peste $55 \%$ din total), în 
timp ce producţia de carne fragedă de o bună calitate, reprezentată de juvenili şi subadulţi (animale până în 2 ani) se situează în plan secundar (fig. 3).

Porcul este sacrificat după vârsta de 6 luni ( $80 \%$ din total) şi mai ales în intervalul dintre 1 şi 2 ani (10 din cei 15 indivizi prezumați), ceea ce ar sugera, prin căutarea maximizării randamentului la tăiere în cazul acestui animal, obţinerea unei cantităţi mari de carne (fig. 3).

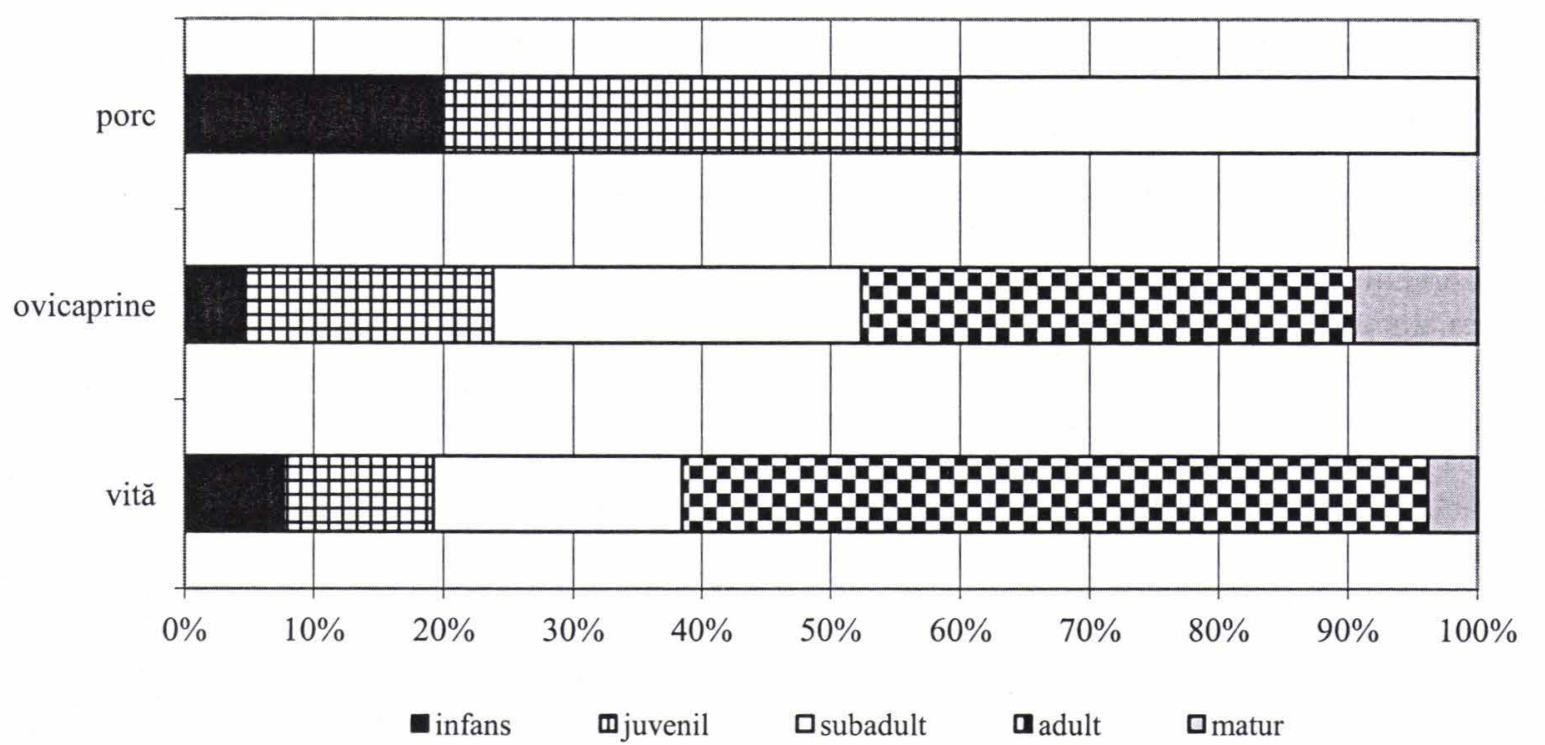

FIGURA 3. Repartiţia vârstelor de sacrificare ale principalelor specii de animale domestice pe clase de vârstă biologică (după Forest 1997)

În încercarea de a înţelege mai bine paleoeconomia comunităților romane din partea de sud-est a României am încercat să comparăm situl de la Ostrov (Durostorum) cu alte așezări contemporane (secolele II-III p. Chr.) din regiune. Astfel de situri sunt relativ puţine şi acestea se găsesc concentrate mai ales în Dobrogea (jud. Tulcea). Acestea sunt: Isaccea/Noviodunum ${ }^{31}$, Niculiţel ${ }^{32}$, Horia ${ }^{33}$ şi Teliţa $\mathrm{Amza}^{34}$.

În cadrul acestor eşantioane faunistice ponderea diferitelor clase de animale (moluşte, peşti şi păsări), în afara mamiferelor, este extrem de scăzută. În consecinţă, în cele ce urmează vom insista doar asupra mamiferelor.

Loturile faunistice sunt relativ reduse ca număr de resturi. Astfel, la Isaccea s-au identificat specific 232 de resturi de mamifere, la Niculiţel 189 de fragmente, la Horia doar 241 de resturi, iar la Teliţa Amza 341. După cum se observă eşantioanele faunistice sunt extrem de sărace, sub 350 de fragmente determinate. În aceste condiţii putem înţelege mai bine importanţa eşantionului faunistic de la Ostrov (Durostorum) care însumează peste 1000 de resturi identificate taxonomic (toate celelalte situri însumate ating această cifră).

În comparaţiile pe care le vom realiza în cele ce urmează vom adăuga şi două aşezări civile romane: cea de la Stolniceni ${ }^{35}$ (jud. Vâlcea), care se constituie într-un eşantion reprezentativ dacă avem în vedere că aproape 932 de resturi de mamifere au fost determinate, și cea de la Barboși ${ }^{36}$ (jud. Galați) cu 1282 resturi determinate specific.

În toate aşezările, mamiferele domestice predomină ca număr de resturi, între $85 \%$ la Teliţa Amza şi peste 99,2\% la Ostrov (Durostorum) și Barboși (fig. 4).

\footnotetext{
${ }^{31}$ Stanc, Bejenaru 2009

${ }^{32}$ Haimovici 1996

${ }^{33}$ Haimovici 1996

${ }^{34}$ Haimovici 2003

${ }^{35}$ Udrescu 1979

${ }^{36}$ Haimovici 1983
} 


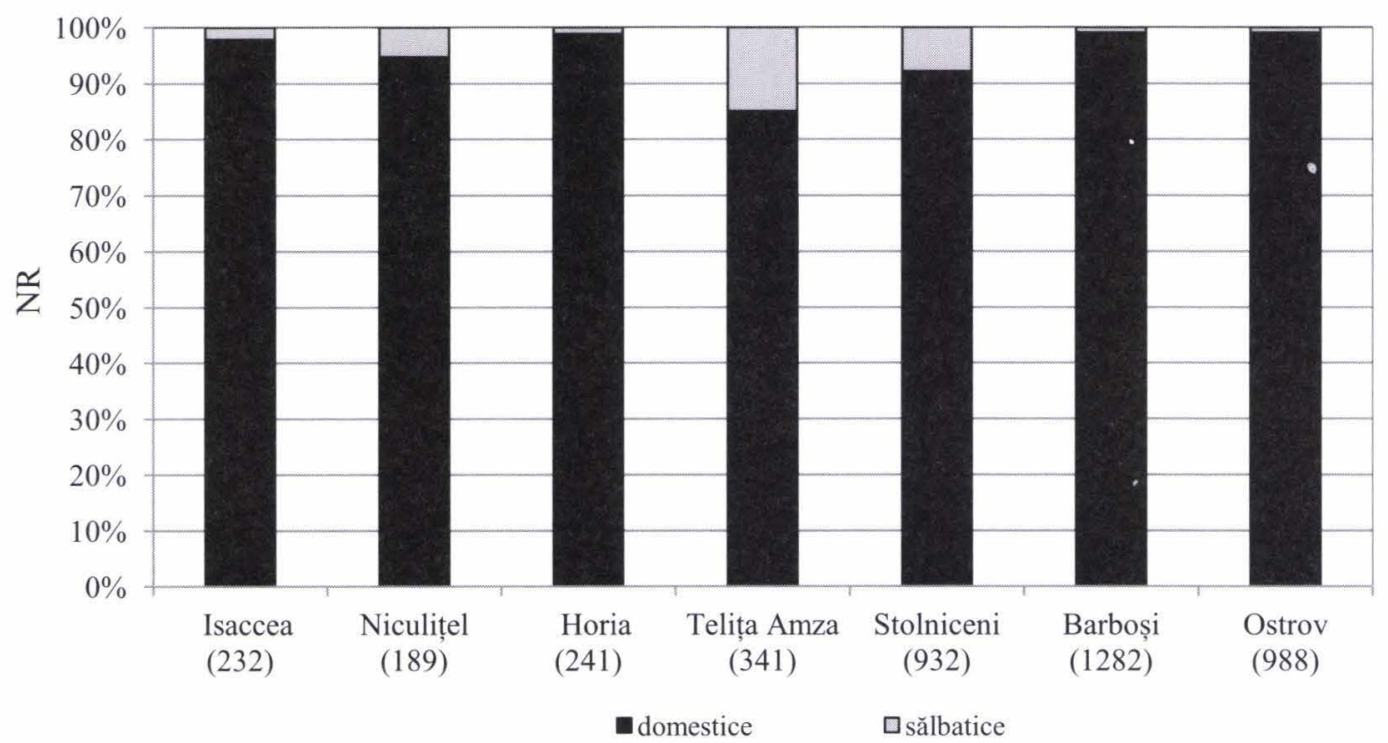

FIGURA 4. Repartiţia procentuală a resturilor faunistice ( $N R=$ număr de resturi) de mamifere pe categorii: domestice şi sălbatice. În paranteză se găseşte numărul de resturi determinate până la nivel de specie

Ca număr minim de indivizi (NMI) situaţia se menţine, doar că ponderea domesticelor este în ușoară scădere, lucru care s-ar putea datora eșantioanelor faunistice reduse care au dus la o suprareprezentare a numărului minim de indivizi. Astfel, animalele domestice prezintă procentaje care variază de la 68,7\% la Teliţa Amza până la 98,8\% la Barboși (fig. 5).

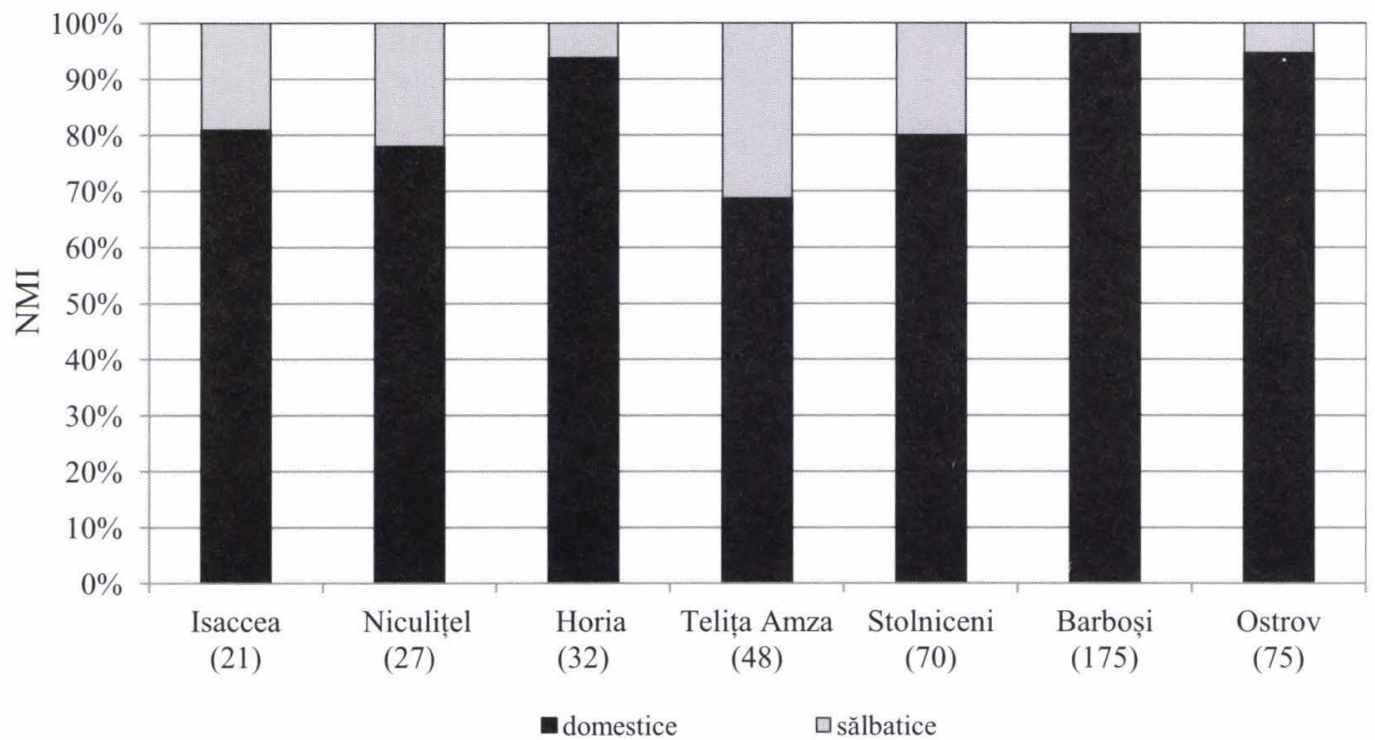

FIGURA 5. Repartiţia procentuală a numărului minim de indivizi (NMI) de mamifere pe categorii: domestice şi sălbatice. În paranteză se găseşte numărul de indivizi determinaţi până la nivel de specie

Această situaţie sugerează că activitatea de creştere a animalelor juca un rol important în viaţa comunităţilor romane. Principalele specii domestice exploatate şi consumate erau: bovinele, ovicaprinele şi porcinele. Calul deşi uneori este consumat în alimentație (dar nu în toate aşezările romane) deţinea o pondere extrem de redusă. Având în vedere aceste aspecte în cele ce urmează vom încerca să surprindem câteva caracteristici ale creșterii principalelor animale (triada domestică: bovine, ovicaprine și porcine) în perioada romană în sud-estul României.

În toate așezările romane luate în discuţie de către noi observăm că bovinele (Bos taurus) se situează pe primul loc, cu procentaje ce variază între 47\% la Stolniceni până la 78\% la Niculițel (fig. 
6). Locul doi este disputat între ovicaprine şi porcine. Astfel, la Isaccea, Niculiţel, Horia, Barboși şi Ostrov, ovicaprinele depăşesc porcinele ca număr de resturi, în timp ce la Telița Amza și Stolniceni porcinele se situează cu puţin înaintea ovicaprinelor (cu 1-2\%).

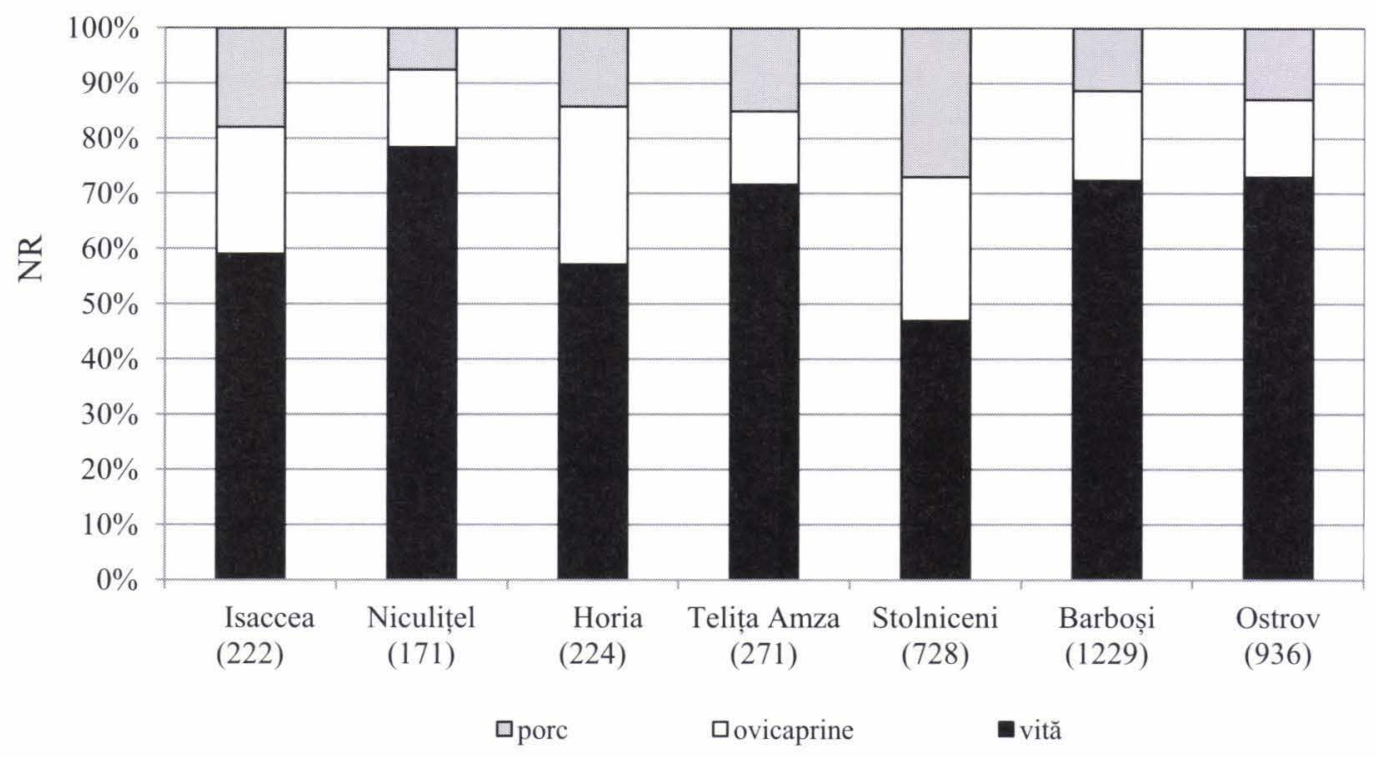

FIGURA 6. Repartiţia procentuală a resturilor faunistice (NR=număr de resturi) ale principalelor specii de mamifere domestice. În paranteză se găsește numărul de resturi determinate

Ca NMI preponderenţa bovinelor se menţine între $41 \%$ la Horia şi Ostrov până la $56 \%$ la Telița Amza, cu excepţia aşezării de la Stolniceni unde porcinele (38\%) depășesc cu puțin bovinele (37\%). În celelalte aşezări ovicaprinele şi porcinele își dispută locul doi, având ponderi relativ egale la Isaccea şi Horia, în timp ce la Niculiţel, Barboși şi la Ostrov, ovicaprinele se situează înaintea porcinelor, iar la Teliţa Amza porcinele surclasează ovicaprinele (fig. 7).

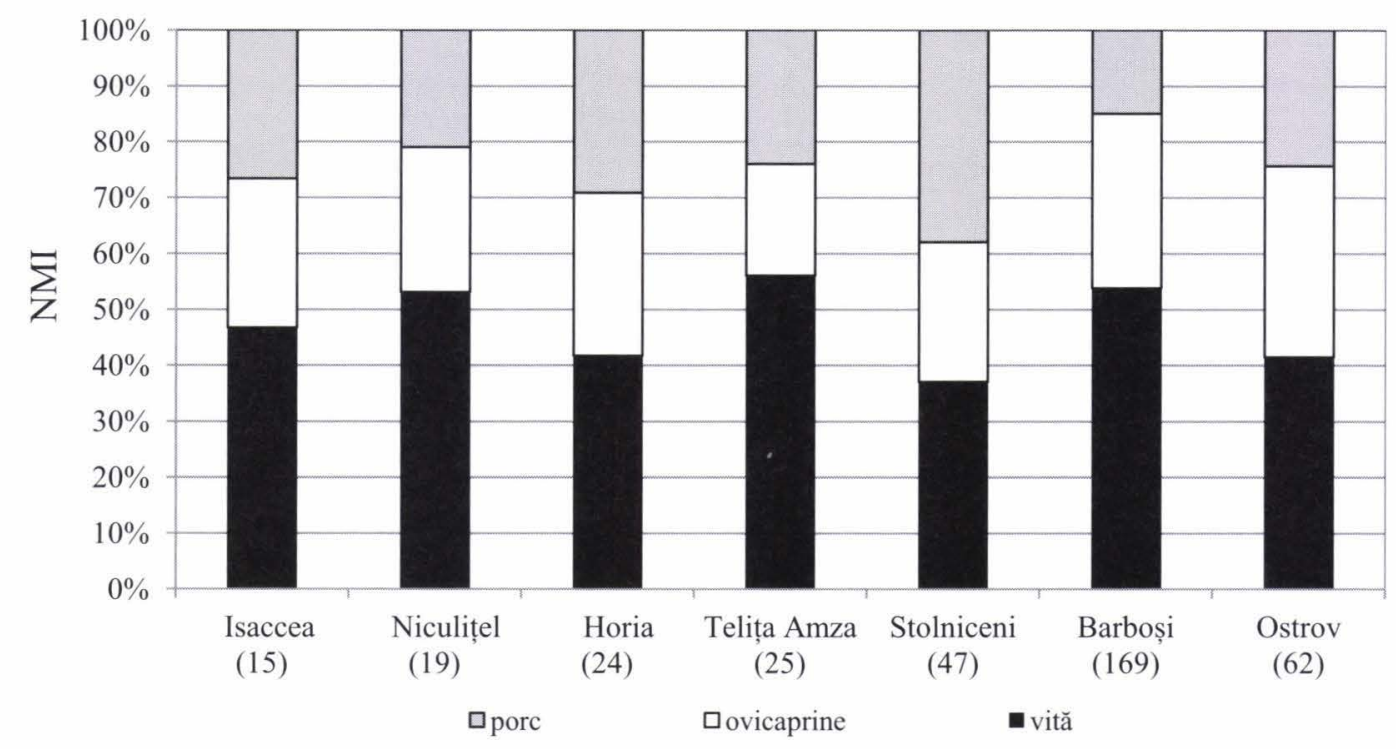

FIGURA 7. Repartiţia procentuală a numărului minim de indivizi (NMI) ale principalelor specii de mamifere domestice. În paranteză se găseşte numărul de indivizi

Vânatul este slab reprezentat, sub $8 \%$ ca NR în majoritatea siturilor, cu excepția aşezării rurale de la Teliţa Amza, unde acesta are o pondere relativ crescută (15\% NR şi 31,3\% NMI), dar fără să 
depăşească importanța creşterii animalelor. Numărul de taxoni identificaţi variază de la două specii descoperite la Horia și Barboși până la 7-8 taxoni identificate la Teliţa Amza şi Stolniceni. Cele mai vânate animale erau cerbul şi mistreţul. Remarcăm de asemenea descoperirea ursului şi a bourului în aşezările de la Niculiţel şi Teliţa Amza. În prezent, ursul este un animal întâlnit doar în zona montană, iar bourul a dispărut deja din fauna lumii.

Vânătoarea avea o pondere relativ scăzută, rolul său fiind mai mult secundar, de suplimentare şi completare a dietei carnate, dar și de eliminare a acţiunii prădătoare a unor specii care afectau culturile agricole sau turmele de animale domestice (carnivorele).

\section{CARACTERIZAREA BIOMETRICĂ A SPECIILOR DE ANIMALE}

Descoperirea unor oase întregi a permis caracterizarea biometrică a populaţiilor de animale domestice existente la Ostrov (Durostorum). Pentru vita domestică avem patru metacarpiene (indice Matolcsi), dintre care două provin de la indivizi castraţi $(120,2$ şi $122,3 \mathrm{~cm})$, unul de la o femelă $(103,1 \mathrm{~cm})$ şi unul de la un mascul $(109,5 \mathrm{~cm})$ și trei metatarsiene care atestă un individ mascul $(126,5$ $\mathrm{cm}$ ) şi două femele $(106,6$ şi $110,3 \mathrm{~cm})$. O medie a taliei vitei domestice de la Ostrov (Durostorum) este de 114, $2 \mathrm{~cm}(\mathrm{~N}=7$, limite 103,1-126,5 cm), dintre care pentru femele ar fi de 106,7 $\mathrm{cm}(\mathrm{N}=3)$, pentru castraţi de $121,6 \mathrm{~cm}(\mathrm{~N}=2)$, iar pentru masculi de $118 \mathrm{~cm}(\mathrm{~N}=2)$.

Comparativ cu așezările romane de la Telița Amza, Horia ${ }^{37}$ și Stolniceni ${ }^{38}$ media taliei vitelor de la Ostrov (Durostorum) este mai mică, dar este mai mare față de vitele de la Barboșis ${ }^{39}$. Comparativ cu vitele din așezările geto-dacice de la sud de Carpați (Cârlomănești, Radovanu, Zimnicea și Mărgăritești ${ }^{40}$ ), valorile sunt apropiate, în timp ce aceste talii sunt superioare față de cele obținute în situl de la Bordușani Popină ${ }^{41}$.

Datele biometrice ale vitelor de la Ostrov (Durostorum) (anexa 2) ne indică că majoritatea indivizilor sunt de talie medie spre mică ceea ce ar sugera că acestea provin mai degrabă din fondul autohton geto-dacic. În acest moment al cercetării arheozoologice de la Ostrov (Durostorum), puține date provin de la animale de talie mare care ar putea fi exemplare ameliorate aduse de romani sau obținute prin controlul reproductiv al animalelor cu tauri de prăsila de talie mare probabil de origine romană.

Ovinele (Ovis aries) au putut fi caracterizate pe baza a două metacarpiene (indice Teichert), media fiind de $57,8 \mathrm{~cm}$ (limite $53,1-62,6 \mathrm{~cm}$ ). Această valoare este inferioară celei obţinute în aşezările romane contemporane de la Horia, Telița $\mathrm{Amza}^{42}$, Barboși ${ }^{43}$ şi Stolniceni ${ }^{44}$, dar superioară valorilor ovinelor din așezările geto-dacice de la Cârlomănești, Radovanu și Zimnicea ${ }^{45}$.

Caprinele (Capra hircus) prezintă o medie a taliei de $63,1 \mathrm{~cm}$ (indice Schramm), valoare obţinută pe baza unui metacarpian $(63,2 \mathrm{~cm})$ şi a trei metatarsiene $(57,4 ; 64,1$ şi $67,8 \mathrm{~cm})$. Valoarea medie este superioară dimensiunilor caprei de la Horia ${ }^{46}$ și apropiată de cea din situl geto-dacic de la Bordușani Popină ${ }^{47}$.

Porcinele (Sus domesticus) prezintă mai multe elemente anatomice întregi care au permis obținerea următoarelor valori ale taliei (indice Teichert): două calcanee $(63,3$ şi $65,6 \mathrm{~cm})$, două metacarpiene III $(73,2$ şi 72,4 cm), un metacarpian IV $(76 \mathrm{~cm})$ şi un metatarsian IV $(72,1 \mathrm{~cm})$. Media taliei are o valoare de $70,4 \mathrm{~cm}(\mathrm{~N}=6)$ ceea ce sugerează animale de talie medie, neameliorate din punct de vedere rasial și extrem de apropiate ca dimensiuni de media obținută în așezarea geto-dacică de la Borduşani Popinăă .

\footnotetext{
${ }^{37}$ Stanc 2009

${ }^{38}$ Udrescu 1979

${ }^{39}$ Haimovici 1983

${ }^{40}$ Vezi Udrescu 1979

${ }^{41}$ Bălăşescu 1997

42 Stanc 2009

${ }^{43}$ Haimovici 1983

${ }^{44}$ Udrescu 1979

${ }^{45}$ Udrescu 1979

${ }^{46}$ Haimovici 1996

${ }^{47}$ Bălășcscu 1997

${ }^{48}$ Bălăşescu 1997
} 
Calul (Equus caballus) prezintă doar două oase întregi care au furnizat următoarele valori (indice Kiesewalter): $142,3 \mathrm{~cm}$ (metacarp) şi $138 \mathrm{~cm}$ (metatars). Talia medie a calului de la Ostrov $(140,1 \mathrm{~cm})$ este superioară valorilor obținute la Telița $\mathrm{Amza}^{49}$, dar și față de alte așezări geto-dacice: Zimnicea, Radovanu și Mărgăritești ${ }^{50}$. Dimensiunile celor două metapodii de la Ostrov ne arată că aceste animale erau de talie medie (după scara lui Vitt ${ }^{51}$ ). În ceea ce privește indicii de gracilitate, acești cai aveau extremități submedie după metacarp și subțiri după metatars.

Câinele (Canis familiaris) prezintă trei oase întregi care au furnizat următoarele talii (indice Koudelka/ Harcourt): 56,8/- cm (scapulă), 53,8/50,2 cm (humerus) și 51,5/52,4 cm (femur). Media taliei după Koudelka este de $54 \mathrm{~cm}(\mathrm{~N}=3)$, iar după Harcourt este de $51,3 \mathrm{~cm}(\mathrm{~N}=2)$. Aceste valori ne indică animale cu o talie supramedie și de o robustețe mijlocie ${ }^{52}$. Valorile obținute sunt inferioare celor descoperite la Bordușani Popină ${ }^{53}$.

Datele biometrice prelevate din eșantionul faunistic de la Ostrov (Durostorum) ne relevă că animalele domestice întâlnite în acest sit au mai multe în comun cu fondul autohton (geto-dacic) decât cu influența romană asupra ameliorării rasiale a animalelor. Puține fragmente osoase studiate din punct de vedere morfometric par a indica această influență, care este extrem de redusă, aceasta rezumânduse în acest stadiu al cercetării doar la bovine și cabaline.

\section{CONCLUZII}

Studiul arheozoologic realizat asupra faunei din așezarea civilă de la Ostrov (Durostorum) ne relevă faptul că, în cadrul acestei comunităţi umane, activitatea de creştere a animalelor avea un rol important. Astfel, bovinele domină, atât ca număr de resturi, cât şi ca număr minim de indivizi, ele fiind urmate de către ovicaprine și porcine. Calul era și el folosit în alimentație.

Vârstele de sacrificare ale principalelor specii ne arată că bovinele şi ovicaprinele sunt crescute în special pentru produsele lor secundare, lapte şi forță de tracţiune în cazul cornutelor mari şi lapte şi lână în cazul comutelor mici. În plan secundar aceste animale erau crescute şi pentru producţia de came. Porcul era sacrificat mai ales între 1 şi 2 ani când acest animal atinge o greutate ponderală mare.

Comparativ cu alte aşezări romane din sud-estul României din aceiaşi perioadă (secolele II-III p. Chr.), aşezarea de la Ostrov (Durostorum) se încadrează în aceeaşi parametri caracteristici ai paleoeconomiei animaliere în care activitatea de creștere a animalelor, în special a bovinelor este predominantă, iar vânatul este slab reprezentat.

Prin prisma datelor faunistice actuale de la Ostrov (Durostorum) vânatul şi păsările domestice sunt slab reprezentate. De asemenea, culesul scoicilor se pare că îi interesa pe locuitorii de aici. În ceea ce priveşte peştele nu avem nicio informaţie deocamdată cu toate că în alte situri romane din aceeaşi perioadă pescuitul este atestat ${ }^{54}$.

Studiul acestui prim lot de resturi faunistice de la Ostrov (Durostorum) este foarte important pentru perioada secolelor II-III p. Chr fiind singurul din sudul Dobrogei. El ne oferă deocamdată o imagine sumară a paleoeconomiei animaliere din aşezările romane care pe viitor va fi îmbunătăţită cu mai multe detalii (modalităţi de tranşare, patologie etc.) prin studiul unor noi eşantioane faunistice.

\section{MULTUMIRI}

Dorim să mulţumim pe această cale arheologilor Crişan Muşețeanu (Muzeul Naţional de Istorie a României) şi Dan Elefterescu (Muzeul „Dunării de Jos”, Călăraşi), care ne-au încredințat spre studiu materialul faunistic descoperit la Ostrov (Durostorum) între anii 1997-1998. Nu în ultimul rând ne exprimăm gratitudinea fałă de Adela Bâltâc şi Paul Damian (Muzeul Naţional de Istorie a Românici), care ne-au sprijinit în efortul nostru de a înf̧elege mai bine situaţia arheologică din acest sit.

\footnotetext{
${ }^{49}$ Haimovici 2003

${ }^{50}$ Udrescu 1979

${ }^{51}$ Vitt 1952

52 Udrescu 1990

${ }^{53}$ Bălāşescu 1997

${ }^{54}$ Haimovici 1996; Haimovici 2003; Stanc, Bejenaru 2009; Stanc et alii 2009
} 


\section{BIBLIOGRAFIE}

Balasse, Ambrose 2005

Barone 1986

Bălășescu 1997

Boessneck, Muller Teichert 1964

Clutton-Brock et alii 1990

Culică 1978

Damian, Bâltâc 2008

von den Driesch 1976

von den Driesch, Boessneck 1974

Ducos 1968

Elefterescu 2011

Forest 1997

Grant 1982

Haimovici 1983

Haimovici 1996

Haimovici 2003

Hallstead et alii 2003

Helmer 2000

Horard-Herbin 1997

Mușeţeanu 2003

Payne 1973

Payne 1985

Popovici et alii 2002
M. Balasse, S.H. Ambrose, Distinguishing sheep and goats using dental morphology and stable carbon isotopes in C4 grassland environments, Journal Archaeological Science, 32, 2005, p. 691-702

R. Barone Anatomie compare des mammifères domestiques, $3^{\mathrm{e}}$ éd., Paris, vol. I, 1986

A. Bălăşescu, Archaeozoology (La Tène), $C A, 10,1997$, p. 48-63

J. Boessneck, H.H. Muller, M. Teichert, Osteologische Unterscheidungsmerkmale zwischen Schaf (Ovis aries Linnaeus) und Ziege (Capra hircus Linnaeus), KuhnArchiv, 78, 1964, p. 1-129

J. Clutton-Brock, K. Dennis-Bryan, P.A. Armitage, P.A. Jewell, Osteology of the Soay Sheep, Bulletin British Museum Natural History, 56, 1990, p. 1-56

V. Culică, Cu privire la lagărul legiunii a XI-a Claudia la Dunărea de Jos, Pontica, 11, 1978, p. 113-118

P. Damian, A. Bâltâc, The civil roman settlement at Ostrov-Durostorum, Istros, 14,2008 , p. $61-70$

A. von den Driesch, A guide to the measurement of animal bones from archaeological sites, Peabody Museum Bulletin, 1 (Harvard University), 1976

Driesch von den A., Boessneck J., Kritische Anmerkungen zur WiderristhohenBerechnung aus langmassen vor- und fruhgeschichtlicher Tierknochen, Saugetierkundliche Mitteilungen, 22 (4), 1974, p. 325-348

P. Ducos, L'origine des animaux domestique en Palestine, Bordeaux, Publications de l'Institut de l'Université de Bordeaux, 6, 1968

D. Elefterescu, Obiecte din os de la Durostorum (I), Pontica, 41, 201 1, p. 219-297

V. Forest, Données biologiques et données zootechniques anciennes. Essai de mise en équivalence, Revue de Médicine Vétérinaire, Toulouse 148, 12, 1997, p. 951958

A. Grant, The use of tooth wear as a guide to the age of domestic ungulates, in B. Wilson, C. Grigson, S. Payne. Ageing and Sexing Animal Bones from Archaeological Sites, $B A R, 109,1982$, p. 91-108

S. Haimovici, Studiul materialului paleofaunistic din aşezarea romană de la Barboși din secolele II-III e.n., Hierasus, V, 1983, p. 211-220

S. Haimovici, Studiul arheozoologic al materialului din două villae romanae din Nordul Dobrogei prin comparaţie cu situri autohtone contemporane lor, Peuce, 12, 1996, p. 393-407

S. Haimovici, Studiul arheozoologic al resturilor din două nivele aparţinând sec. II-III şi IV p. Chr., găsite în situl autohton de la Teliţa-Amza (nordul Dobrogei), Peuce S.N., XIV, 2003, p. 487-510

P. Hallstead, P. Collins, V. Isaakidou, Sorting the sheep from the goats: morphological distinctions between the mandibles and mandibular teeth of adult Ovis and Capra, Journal of Archaeological Science, 29, n. 5, 2003, p. 545-554

D. Helmer, Discrimination des genres Ovis et Capra à l'aide des prémolaires inférieures 3 et 4 et interprétation des âges d'abattage : l'exemple de Dikili Tash (Grèce), Anthropozoologica, 31, Ibex Journal of Mountain Ecology, 5, 2000, p. 29-38

M.-P. Horard-Herbin, Le village celtique des Arènes à Levroux. L'élevage et les productions animales dans l'économie de la fin du second Age du Fer, $12^{\text {eme }}$ supplément à la Revue du Centre de la France, Levroux 4, 1997

C. Muşeteanu (în colaborare cu D. Elefterescu), Ateliere ceramice romane de la Durostonum, Monografii IV, Muzeul Naţional de Istorie a României, Bucureşti, 2003

S. Payne, Kill-off patterns in sheep and goat: the mandibles from Asvan Kale, Anatolian Studies, 23, 1973, p. 281-303

S. Payne, Morphological distinction between the mandibular teeth of young sheep, Ovis and goats, Capra, Journal of Archaeological Science, 12, 1985, p. 139-147

D. Popovici, A. Bălăşescu, C. Haită, V. Radu, A.M.F. Tomescu, I. Tomescu, Cercetarea arheologică pluridisciplinară. Concepte, metode şi tehnici, Biblioteca Muzeului Naţional, Seria Cercetări Pluridisciplinare, 3, Bucureşti, 2002 
Prummel, Frisch 1986

Schmid 1972

Stanc 2009

Stanc, Bejenaru 2009

Stanc et alii 2009

Udrescu 1979

Udrescu 1990

Udrescu, Bejenaru, Hrișcu 1999

Vitt 1952
W. Prummel, H.J. Frisch, A Guide for the Distinction of Species, Sex and Body in Bones of Sheep and Goat, Journal of Archaeological Science, 13, 1986, p. 567-577

E. Schmid, Atlas of Animal Bones, Amsterdam-London-New York, Elsevier Publishing Company, 1972

S.M. Stanc, Arheozoologia primului mileniu după Hristos pentru teritoriul cuprins intre Dunăre şi Marea Neagră, Iaşi, 2009

S.M. Stanc, L. Bejenaru, The Archaeozoological Analysis of a Sample of Roman Period of the Isaccea Site, Analele Ştiintifice ale Universitătii „Al. I. Cuza" Iaşi, s. Biologie animală, LV. 2009, p. 229-234

S.M. Stanc, V. Radu, L. Bejenaru, Cyprinid fishing in Dobrudja (Romania) from prehistory to the Middle Ages, in D. Makowiecki, S. Hamilton-Dyer, I. Riddler, N. Trzaska-Nartowski, M. Makohonienko (eds.), Fishes - Culture - Environment Through Archaeoichthyology, Ethnography and History, the $15^{\text {th }}$ Meeting of the ICAZ Fish Remains Working Group (FRWG), September 3-9, 2009 in Poznan \& Torun, Poland, Srodowisko I Kultura (Environment and Culture), vol. 7, Bogucki Wydawnictwo Naukowe, Poznan, 2009, p. 108-113

M. Udrescu, Aşezarea civilă romană de la Stolniceni; unele date despre influenţa romaná asupra creşterii animalelor în Dacia. Studiu arheozoologic, Revista Muzeelor si Monumentelor, 9-10, 1979, p. 101-108

M. Udrescu, Les chiens de l'habitat civil Romain de Stolniceni-Valcea; données zooarchéologiques, Annuaire Roumain d'Anthropologie, 27, 1990, p. 3-8

M. Udrescu, L. Bejenaru, C. Hrişcu, Introducere in arheozoologie, Iaşi, 1999

V.O. Vitt, Loshadi Pezyryksich kuganov, Sovetskaja Archeologija, 16, 1952, p. $163-205$

\section{LISTE DES FIGURES}

Figure 1. Décompte des restes fauniques issus du niveau culturel (nc) et complexes archéologiques (g) de Durostorum

Figure 2. Distribution des restes fauniques (NR) et du nombre minimal des individus (NMI) par espèces de mammifères

Figure 3. Répartition de l'âge d'abatage des principaux animaux domestiques par clases d'âge (d'après Forest 1997)

Figure 4. Fréquence des restes fauniques de mammifères (NR = nombre de restes) par catégories : domestique et sauvage. Entre les parenthèses il y a le nombre des restes déterminés par chaque espèce

Figure 5. Fréquence du nombre minimal des individus de mammifères (NMI) par catégories : domestique et sauvage. Entre les parenthèses il y a le nombre d'individus déterminés par chaque espèce

Figure 6. Fréquence des restes fauniques ( $N R=$ nombre de restes) de principales espèces de mammifères domestiques. Entre les parenthèses il y a le nombre des restes déterminés

Figure 7. Fréquence du nombre minimal des individus de mammifères (NMI) de principales espèces de mammifères domestiques. Entre les parenthèses il y a le nombre d'individus

Annexe 1. Répartition des restes par éléments anatomiques

Annexe 2. Biométrie. Les mesures retenues sont celles défines par von den Driesch (1976) et elles sont exprimées en millimètres

Pl. I. 1. Neurocrâne de bœuf (Bos taurus) sans comes; 2. Os coxaux gauche de bœuf (Bos taurus) à traces de découpe au niveau de l'articulation acétabulaire; 3. Scapula de bœuf (Bos taurus) à traces de découpes longitudinales sur la tête scapulaire (a gauche), détaille (a droite); 4. Humérus de bœuf (Bos taurus) à traces de découpes longitudinales (vue craniale)

Pl. II. 1. Radius de bœuf (Bos taurus) à traces de découpes longitudinales (vue dorsale et vue palmaire) ; 2 . Métatarse de bœuf (Bos taurus) à traces de découpes longitudinales; 3. Cheville osseuse de chèvre (Capra hircus) ; 4. Mandibule de mouton (Ovis aries) ; 5. Mandibule d'un porc mâle (Sus domesticus) avec des traces de brûlure dans la zone des incisives et des canins ; 6. Mandibule de porc (Sus domesticus) ; 7. Radius de blaireau (Meles meles) 


\begin{tabular}{|c|c|c|c|c|c|c|c|c|c|c|c|}
\hline 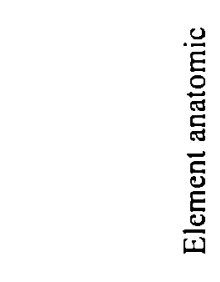 & 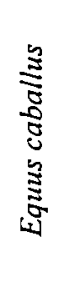 & 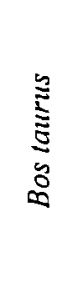 & $\underbrace{\frac{0}{2}}_{\frac{2}{3}}$ & 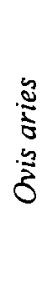 & $\begin{array}{l}\frac{3}{0} \\
\frac{0}{2} \\
0 \\
\frac{0}{3} \\
0\end{array}$ & 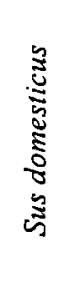 & & $\begin{array}{l}\frac{y}{3} \\
\frac{5}{0} \\
\frac{2}{2} \\
\frac{2}{2} \\
\frac{5}{2} \\
0\end{array}$ & $\begin{array}{l}3 \\
3 \\
0 \\
0 \\
0 \\
0 \\
0 \\
3 \\
0 \\
0 \\
0 \\
0 \\
0\end{array}$ & $\begin{array}{l}0 \\
5 \\
5 \\
5 \\
5 \\
5 \\
5 \\
5\end{array}$ & 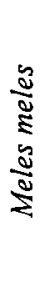 \\
\hline Schelet intreg & & & & & & 1 & 1 & & & & \\
\hline Coame & & & & & & . & & 2 & & & \\
\hline Cranium & & & 1 & & & & & & & & \\
\hline Neurocranium & 1 & 27 & 1 & 4 & 13 & 2 & & & 1 & & \\
\hline Viscerocranium & 2 & 43 & 4 & & & 19 & 1 & & & & \\
\hline Mandibula & 3 & 28 & 22 & & & 26 & 2 & & & & \\
\hline Dentes sup. & 1 & & & & & 1 & & & & & \\
\hline Dentes inf. & 1 & & & & & 2 & & & & 1 & \\
\hline Hyoid & & 3 & & & & & & & & & \\
\hline Atlas & & 7 & & & & & 1 & & & & \\
\hline Epistropheus & 1 & 6 & & & & & & & & & \\
\hline et Vert. cv. & 1 & 15 & & & & & & & & & \\
\hline Vert. thor. & & 55 & 3 & & & & & & & & \\
\hline Vert. lumb. & & 27 & 2 & & & 1 & & & & & \\
\hline Sacrum & & 1 & & & & & & & & & \\
\hline Costae & & 40 & & & & 4 & & & & & \\
\hline Scapula & 1 & 23 & 6 & 2 & & 11 & 1 & 1 & & & \\
\hline Humerus & & 22 & 3 & 1 & 1 & 8 & 3 & & & & \\
\hline Radius & & 19 & 1 & 1 & 3 & 6 & 2 & & & & 1 \\
\hline Ulna & & 9 & 4 & & & 8 & 4 & & & & \\
\hline Radio-Ulna & & 2 & & & & & & & & & \\
\hline Carpalia & & 4 & & & & & & & & & \\
\hline Metacarpus & 2 & 69 & 6 & 1 & 6 & 5 & & & & & \\
\hline Pelvis & 2 & 35 & 2 & & & 4 & 1 & & & & \\
\hline Femur & 2 & 39 & 3 & & & 2 & 2 & & & & \\
\hline Patella & & 1 & & & & & & & & & \\
\hline Tibia & 1 & 20 & 7 & 4 & 1 & 6 & 3 & & & & 1 \\
\hline Fibula & & & & & & 2 & & & & & \\
\hline Calcaneus & & 16 & & & & 3 & & & & & \\
\hline Talus & & 11 & 2 & & & & & & & & \\
\hline et Tarsalia & & 6 & & & & & & & & & \\
\hline Metatarsus & 1 & 46 & 12 & 2 & 3 & 2 & & 1 & & & \\
\hline Metapodalia & 2 & 12 & 6 & & & & 1 & & & & \\
\hline Phalanx 1 & & 66 & 1 & & & & & & & & \\
\hline Phalanx 2 & & 21 & & & & & & & & & \\
\hline Phalanx 3 & & 22 & & & & & & & & & \\
\hline Maleolar & & 1 & & & & & & & & & \\
\hline Total NR & 21 & 696 & 86 & 15 & 27 & 113 & 22 & 4 & 1 & 1 & 2 \\
\hline
\end{tabular}

ANEXA 1. Repartitia pe elemente anatomice a resturilor de mamifere 
ANEXA 2. Biometrie. Toate măsurătorile sunt

după von den Driesch (1976) şi sunt exprimate în milimetri

\section{Bos taurus}

Mandibula

\begin{tabular}{|l|c|c|c|c|}
\hline 7 & 135 & & & \\
\hline 8 & 86.2 & 74.9 & 80.8 & 86 \\
\hline 9 & 48 & & & \\
\hline $10 \mathrm{~L}$ & & 33.2 & 36 & \\
\hline $10 \mathrm{~B}$ & & 15.3 & 15.5 & \\
\hline
\end{tabular}

\section{Scapula}

\begin{tabular}{|l|c|c|c|c|c|c|}
\hline SLC & 63 & 58.5 & 57.4 & & 48.5 & 42 \\
\hline GLP & 79 & 71.5 & 74 & 71 & & \\
\hline LG & 64 & 61 & 62.5 & 59.5 & 54.5 & \\
\hline BG & 56 & 49.6 & 54.8 & 47.5 & & \\
\hline
\end{tabular}

Humcrus
\begin{tabular}{|l|c|c|c|c|}
\hline Bd & 79 & & & 63.9 \\
\hline BT & 75 & 80 & 67 & 60.8 \\
\hline DU & & & & 60.2 \\
\hline
\end{tabular}

Radius
\begin{tabular}{|l|l|l|l|l|l|l|l|}
\hline $\mathrm{Bp}$ & & 70 & 67.4 & & & & \\
\hline $\mathrm{BFp}$ & 85.5 & 65 & 64.1 & & & & \\
\hline $\mathrm{Bd}$ & & & & 75 & 68.5 & 76.5 & 65.4 \\
\hline $\mathrm{BFd}$ & & & & 66.5 & 61.5 & 75 & \\
\hline
\end{tabular}

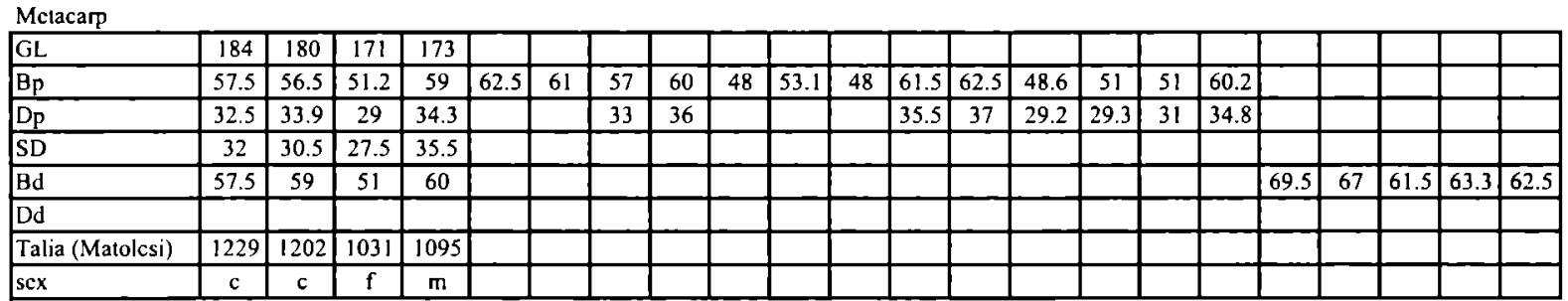

sex

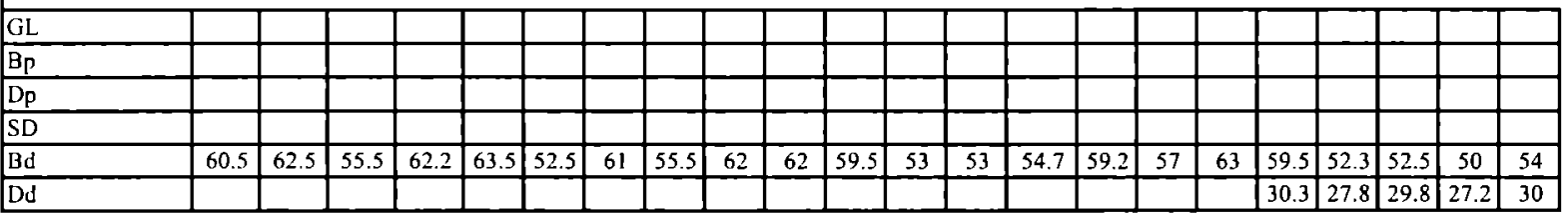

Tibic
\begin{tabular}{|l|c|c|c|c|}
\hline Bp & 86 & & & \\
\hline Dp & 81.9 & & & \\
\hline Bd & & 56.5 & 64.8 & 72 \\
\hline Dd & & 37.7 & 50.1 & \\
\hline
\end{tabular}

\begin{tabular}{|c|c|c|c|c|c|c|c|c|c|c|c|c|c|}
\hline \multicolumn{14}{|l|}{ Mctatars } \\
\hline $\mathrm{GL}$ & 225 & 200 & 207 & & & & & & & & & & \\
\hline $\mathrm{Bp}$ & 52.5 & 41.8 & 43 & 49.3 & 49 & 52.2 & 49.8 & 43 & 46.8 & 42.1 & 51.2 & 51.1 & 43.8 \\
\hline $\mathrm{Dp}$ & 48.4 & & 40 & & & 47.2 & 48.5 & 39.6 & 46.3 & 39.5 & 47.9 & & 39.6 \\
\hline SD & 29.4 & 25.7 & 23 & & & & & & & & & & \\
\hline $\mathrm{Bd}$ & 60 & 48 & 48.2 & & & & & & & & & & \\
\hline \multicolumn{14}{|l|}{ Dd } \\
\hline Talia (Matolcsi) & 1265 & 1066 & 1103 & & & & & & & & & & \\
\hline $\operatorname{sex}$ & $\mathrm{m}$ & $\mathrm{f}$ & $\mathrm{f}$ & & & & & & & & & & \\
\hline & & & & & & & & & & & & & \\
\hline $\mathrm{GL}$ & & & & & & & & & & & & & \\
\hline \multicolumn{14}{|l|}{$\mathrm{Bp}$} \\
\hline \multicolumn{14}{|l|}{ Dp } \\
\hline \multicolumn{14}{|l|}{ SD } \\
\hline $\mathrm{Bd}$ & 67 & 60.5 & 66 & 56.5 & 62.5 & 50.5 & 63.5 & 49.5 & 55.8 & 50.2 & 52.7 & 57.8 & 59.3 \\
\hline Dd & & & & & & & & & & & & 32.8 & 31.6 \\
\hline
\end{tabular}


ANEXA 2. Biometrie. Toate măsurătorile sunt dupã von den Driesch (1976) şi sunt exprimate în milimetri

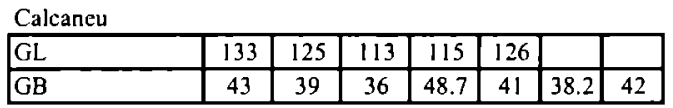

Astragal
\begin{tabular}{|l|c|c|c|c|c|c|}
\hline GLl & 61.2 & 63.5 & 61 & 58.7 & 65 & 57.5 \\
\hline GLm & 56.3 & 58.3 & 56.5 & 55.4 & & \\
\hline Dl & 34 & 30.2 & 34.2 & 32.6 & 37 & 32 \\
\hline Dm & 35.2 & 37 & 34 & 34.3 & 38.5 & 32 \\
\hline Bd & 40 & 43 & 37.2 & 39.2 & 40.5 & 37 \\
\hline
\end{tabular}

\begin{tabular}{|c|c|c|c|c|c|c|c|c|c|c|c|c|c|c|c|c|c|c|c|c|c|c|}
\hline GLp & 49 & 60 & 53 & 61 & 56 & 58 & 60.5 & 61 & 57 & 69.6 & 54 & 58 & 56 & 55 & 62.1 & 157.5 & 51.2 & 57.5 & & 756.5 & & \\
\hline Bp & 27 & 30 & 33 & 32.2 & \begin{tabular}{|l}
30.5 \\
\end{tabular} & 34 & 29.5 & 32 & 26 & 33 & \begin{tabular}{|l|l}
32.7 \\
\end{tabular} & 31.2 & 33 & 30.5 & 533.5 & 33.2 & 23.3 & 29 & \begin{tabular}{|l|}
33 \\
\end{tabular} & 33 & 30 & 30.5 \\
\hline SD & 22.5 & 26 & 26 & 28 & \begin{tabular}{|l|}
27 \\
\end{tabular} & 29 & 26 & 24.5 & 20.5 & \begin{tabular}{|l|l|}
30 \\
\end{tabular} & 27.5 & 23.5 & 27.8 & 25 & 28.5 & 29.7 & 21 & & & & & \\
\hline$B d$ & 26 & 29 & 28.5 & & 29 & \begin{tabular}{|l|l}
32.2 \\
\end{tabular} & 27.7 & 28 & 23.2 & 33.5 & \begin{tabular}{|l}
299.5 \\
\end{tabular} & 27.5 & 30.4 & 29 & 30.5 & 32.2 & 22.3 & 27 & 28.5 & 29 & 27.7 & 28 \\
\hline
\end{tabular}

\begin{tabular}{|l|c|c|c|c|c|c|c|c|c|c|c|c|c|c|c|c|c|c|c|c|c|c|}
\hline $\mathrm{GLP}$ & 54.5 & 51.5 & 57 & 58 & 56.2 & 59 & 58 & 52.1 & 57.5 & 54.5 & 54.5 & 68 & & 60 & 52 & 55.5 & 54.5 & 60 & 54 & 60 & 61.5 & \\
\hline $\mathrm{Bp}$ & 27 & 24.4 & 27.5 & 35.2 & 30.5 & 32.5 & 34 & 25 & 27 & 27 & 29 & 33 & 34 & 30.5 & 34 & 30 & 31.5 & 32 & 25 & 27.5 & 33.5 & 25.5 \\
\hline $\mathrm{SD}$ & & & & & & 27.5 & 29.5 & 22 & 24 & 22 & 22 & 32 & 28.5 & 25.2 & 27 & 25.5 & 26.5 & 25.5 & 21 & 23.2 & 26.5 & \\
\hline $\mathrm{Bd}$ & 24.5 & 22 & 27.3 & 32.3 & 28 & 29.5 & 34 & 24 & 26.5 & 25.5 & 28.5 & 34 & & 29.5 & 28 & 28.5 & & 29.7 & 24 & 26.1 & 30 & \\
\hline
\end{tabular}

\begin{tabular}{|l|c|c|c|c|c|c|c|c|c|c|c|c|c|c|c|c|c|c|c|c|}
\hline GLp & 60.5 & 59 & 60.5 & 59.5 & 62 & 55 & 50.5 & 55 & 52.7 & 57 & 57.5 & 56.5 & 57 & 59 & 54.2 & 60.5 & 57 & 68 & 55.5 & 61 \\
\hline Bp & 28.9 & 31.2 & 31 & 31.5 & 30.5 & 27 & 26.5 & 35 & 26.2 & 28.5 & 33.9 & 27 & 26.5 & 33 & 26 & 32 & 30 & 30.2 & 25 & 30.9 \\
\hline SD & 23 & 27.8 & 24 & 26 & 28.2 & 22.5 & 23.5 & 28 & 22 & 24.7 & 29.2 & 23.2 & 21.8 & 28 & 22.2 & 25 & 24.8 & 24 & 20.5 & 26.2 \\
\hline Bd & 27 & 30.6 & 29 & 27.5 & 30 & 24.1 & 24.7 & 29.5 & 23.2 & 28 & 32 & 26 & 26.3 & 29.5 & 25.1 & 28.5 & 25.7 & 26.5 & 23 & 28.5 \\
\hline
\end{tabular}

Falanga 2

\begin{tabular}{|c|c|c|c|c|c|c|c|c|c|c|c|c|c|c|c|c|c|c|c|}
\hline GLp & 40.5 & 36.5 & 38.5 & 33.5 & 32.5 & 38.5 & 40 & 35 & 37.6 & 38.5 & 42 & 37.5 & 31.8 & 35 & 41.8 & 37 & 24 & 32.5 & 34.5 \\
\hline $\mathrm{Bp}$ & 32 & 29.5 & 32 & 27 & 30.5 & 30.5 & 32 & 29 & 29 & 33.5 & 28.5 & 30.5 & 28.5 & 29.2 & 32.5 & 29.5 & 25.2 & 25.5 & 28 \\
\hline $\mathrm{SD}$ & 26.2 & 24.2 & 26 & 20.5 & 25.1 & 24.2 & 24.5 & 22.5 & 24 & 26 & 25.7 & 23.8 & 24 & 22 & 25.5 & 24.5 & 20.6 & 20.4 & \\
\hline $\mathrm{Bd}$ & 29 & 25.5 & 27.2 & 21.8 & 26.2 & 24 & 25.8 & 25 & 26.2 & 26.5 & 24.5 & 25.5 & 24.5 & 23 & 26 & 27.5 & 21.2 & 22.8 & 24.2 \\
\hline
\end{tabular}

Falanga 3

\begin{tabular}{|l|c|c|c|c|c|c|c|c|c|c|c|c|c|c|c|c|c|c|}
\hline DLS & 78 & 75.5 & 79 & 80.2 & 77 & 78 & 67 & 82 & 71.2 & 61 & 74.5 & 75.5 & 70 & 87 & 83.5 & 61.5 & 71.5 & \\
\hline Ld & 56.5 & 63 & 56.5 & 59 & 57 & 59.5 & 53 & 58 & 54.5 & 48.8 & 53 & 54.5 & 54.2 & 59.5 & 63.2 & 54.5 & 56.5 & \\
\hline MBS & 25 & 24.5 & 27.5 & 24.5 & 25.1 & 26.2 & 23.2 & 22 & 25.5 & 23 & 22.5 & 23.5 & 21 & 27 & 25.5 & 21.3 & 26 & 25.5 \\
\hline
\end{tabular}

\section{Ovis aries}

Scapula
\begin{tabular}{|l|c|c|}
\hline GLP & 32.5 & \\
\hline LG & 25 & \\
\hline BG & 19.6 & \\
\hline SLC & 16.5 & 10.3 \\
\hline
\end{tabular}
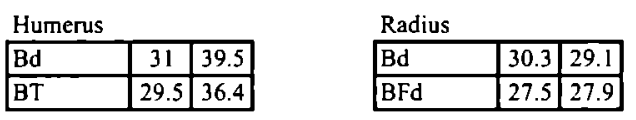

Metacarp
\begin{tabular}{|l|c|c|c|c|}
\hline GL & 128 & 109 & & \\
\hline Bp & 25.5 & 26 & 19.6 & 20.8 \\
\hline SD & 16.5 & 16 & 13.2 & 12.1 \\
\hline Bd & 27.7 & 29 & & \\
\hline Talia (Teicher) & 626 & 531 & & \\
\hline
\end{tabular}
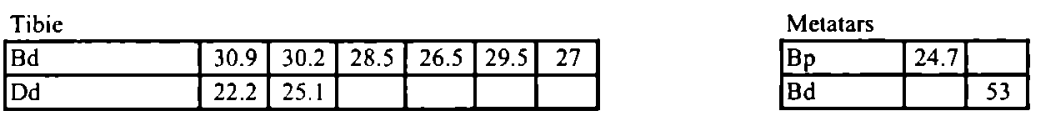
ANEXA 2. Biometrie. Toate măsurătorile sunt dupã von den Driesch (1976) şi sunt exprimate in milimetri

\section{Capra hircus}

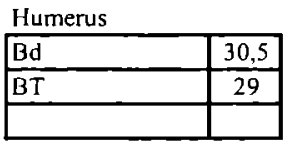

Metatars

\begin{tabular}{|l|c|c|c|c|c|c|c|}
\hline $\mathrm{GL}$ & 127 & 120 & 108 & & & & \\
\hline $\mathrm{Bp}$ & 20,2 & 19,5 & 23,5 & 25,3 & 23,5 & & \\
\hline $\mathrm{SD}$ & 14 & 12 & 13,8 & & & & \\
\hline Bd & 25 & 25 & 26 & & & 25,5 & 26,5 \\
\hline Talia (Schramm) & 678 & 641 & 574 & & & & \\
\hline
\end{tabular}

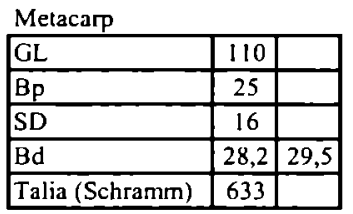

Tibia

Bd 24,2

\section{Sus domesticus}

Mandibula

\begin{tabular}{|l|c|c|c|c|c|c|c|c|c|c|c|c|c|c|c|c|}
\hline 7 & 109 & 103 & 108 & 91,8 & 59,8 & & & & & & & & & & & \\
\hline $7 \mathrm{a}$ & 95 & 87 & 94 & 78,3 & 50,6 & & & & & & & & & & & \\
\hline 8 & 61,5 & 52,5 & 58,5 & 41 & 64 & 61,5 & & & 57 & 62,5 & & & & & & 65 \\
\hline 9 & 46 & 47,5 & 47 & & & & & & & & & & & & & \\
\hline $9 \mathrm{a}$ & 32 & 31 & 33 & & & & & & & & & 34,4 & 32,5 & 34,9 & 33,1 & \\
\hline $10 \mathrm{~L}$ & & & & & & 28,9 & 22,6 & 31,4 & 27 & 32 & 32 & & & & & \\
\hline $10 \mathrm{~B}$ & & & & & & 13 & 14,5 & 11,5 & 13 & 15,2 & 18 & & & & & \\
\hline
\end{tabular}

Maxilar
\begin{tabular}{|l|c|c|c|}
\hline LP1-P4 & 40,5 & & \\
\hline LM1-M3 & 63,5 & 40 & \\
\hline LP1-M3 & 106 & & \\
\hline LM3 & & & 30 \\
\hline IM3 & & & 18,5 \\
\hline
\end{tabular}

Scapula
\begin{tabular}{|l|c|c|c|}
\hline SLC & 20 & 21,5 & 14,6 \\
\hline GL & 31,5 & & \\
\hline GLP & 26 & & \\
\hline BG & 24,5 & & \\
\hline
\end{tabular}

Humerus
\begin{tabular}{|l|c|}
\hline Bd & 37 \\
\hline BT & 28,5 \\
\hline
\end{tabular}

Metacarp III
\begin{tabular}{|l|c|c|}
\hline GL & 71 & 70,2 \\
\hline B & 14 & 14,1 \\
\hline Bd & 18,2 & 16,2 \\
\hline Talia (Teichert) & 732 & 724 \\
\hline
\end{tabular}

Radius
\begin{tabular}{|l|c|c|c|c|}
\hline Bp & 26,5 & 26,5 & & \\
\hline Bd & & & 32 & 33 \\
\hline BFd & & & 27 & 28,7 \\
\hline
\end{tabular}

Metacarp IV

\begin{tabular}{|l|c|}
\hline GL & 75 \\
\hline LeP & 71 \\
\hline B & 12 \\
\hline Bd & 16 \\
\hline Talia (Teichert) & 760 \\
\hline
\end{tabular}

Tibia

\begin{tabular}{|l|l|l|}
\hline Bd & 28 & 22 \\
\hline
\end{tabular}

Calcaneu
\begin{tabular}{|l|c|c|}
\hline LG & 67,5 & 65 \\
\hline BG & 21 & 21,9 \\
\hline Talia (Teicher) & 656 & 633 \\
\hline
\end{tabular}

Metatars IV
\begin{tabular}{|l|c|}
\hline GL & 82 \\
\hline LeP & 78,2 \\
\hline B & 10,8 \\
\hline Bd & 16,5 \\
\hline Talia (Teichert) & 721 \\
\hline
\end{tabular}


ANEXA 2. Biometrie. Toate măsurătorile sunt dupã von den Driesch (1976) şi sunt exprimate în milimetri

\section{Equus caballus}

Scapula
\begin{tabular}{|l|c|}
\hline SLC & 67 \\
\hline GLP & 96.5 \\
\hline LG & 60.1 \\
\hline BG & 47 \\
\hline
\end{tabular}

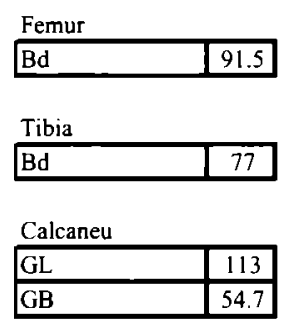

Radius
\begin{tabular}{|l|c|}
\hline Bp & 78 \\
\hline BFp & 74.4 \\
\hline
\end{tabular}

\section{Canis familiaris}

Mandibula

Mandibula
\begin{tabular}{|l|c|c|c|c|}
\hline 1 & 113 & 115 & & \\
\hline 2 & 114 & 116 & & \\
\hline 3 & 109 & 111 & & \\
\hline 4 & 96 & 97 & 121 & \\
\hline 5 & 92.2 & 92.5 & 116 & \\
\hline 6 & 97.8 & 98 & 120 & \\
\hline 7 & & 68 & 79 & \\
\hline 8 & & 66.2 & 74.5 & 69.5 \\
\hline 9 & & 58 & 69.5 & 65.5 \\
\hline 10 & & 33 & 38 & 37 \\
\hline 11 & 36.2 & 36 & 38.5 & 37 \\
\hline 12 & 31 & 32 & 33.8 & 33 \\
\hline $13 \mathrm{a}$ & & & 23 & \\
\hline $13 \mathrm{~b}$ & & & 8.5 & \\
\hline 14 & & & 22 & 19.2 \\
\hline $15 \mathrm{a}$ & 10.1 & 9.7 & & \\
\hline $15 \mathrm{~b}$ & 7.5 & 7.3 & & \\
\hline 18 & & 45 & & \\
\hline 19 & 18.2 & 18.5 & 23 & 25.2 \\
\hline 20 & 17.6 & 18.2 & 18 & \\
\hline
\end{tabular}

Humerus
\begin{tabular}{|l|c|}
\hline GL & 149 \\
\hline Bd & 31.2 \\
\hline Talia (Harcourt) & 502 \\
\hline Talia (Koudelka) & 538 \\
\hline
\end{tabular}

Radius
\begin{tabular}{|l|l|l|}
\hline Bd & 20.5 & 24 \\
\hline
\end{tabular}

Maxilar
\begin{tabular}{|l|c|c|c|c|}
\hline 16 & 18.5 & & & 18 \\
\hline 17 & & & & 37.5 \\
\hline $18 \mathrm{~L}$ & 19 & 14 & 18.7 & \\
\hline $18 \mathrm{~GB}$ & 11 & 7.5 & 11 & \\
\hline $18 \mathrm{~B}$ & 8 & 5.5 & 7.8 & \\
\hline $20 \mathrm{~L}$ & 14.2 & 8.9 & 14 & \\
\hline $20 \mathrm{~B}$ & 16 & 11 & 15.5 & \\
\hline 25 & & & & 56 \\
\hline 34 & & & & 58 \\
\hline
\end{tabular}

Metatars
\begin{tabular}{|l|c|c|}
\hline GL & 267 & \\
\hline GLl & 262 & \\
\hline Ll & 259 & \\
\hline SD & 29.9 & \\
\hline Bd & 48.5 & 47 \\
\hline Talia (Kiesewalter) & 1380 & \\
\hline
\end{tabular}

Coxal
\begin{tabular}{|l|l|}
\hline LA & 65.5 \\
\hline
\end{tabular}

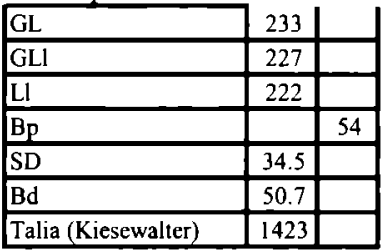

Scapula
\begin{tabular}{|l|r|}
\hline HS & 140 \\
\hline GLP & 32.2 \\
\hline SLC & 25.5 \\
\hline Talia (Koudelka) & 568 \\
\hline
\end{tabular}

\section{Cervus elophus}

Scapula
\begin{tabular}{|l|c|}
\hline GLP & 60.5 \\
\hline LG & 47 \\
\hline SLC & 39.5 \\
\hline
\end{tabular}





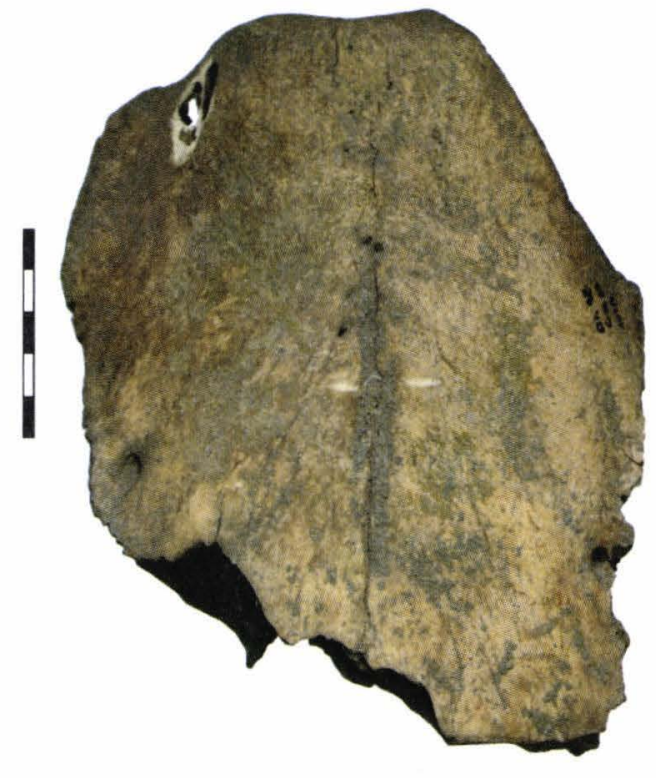

1.

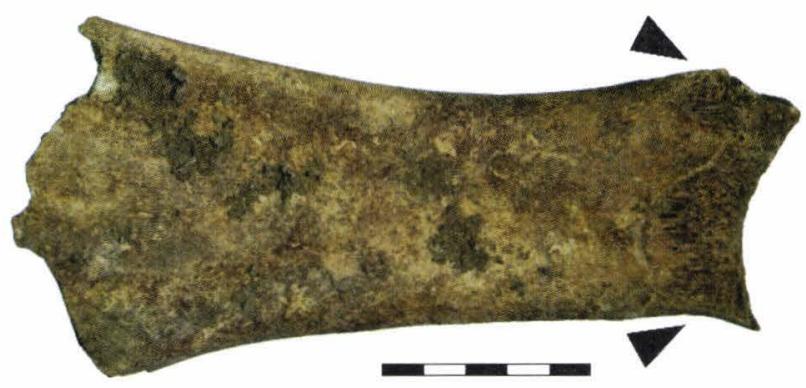

3.
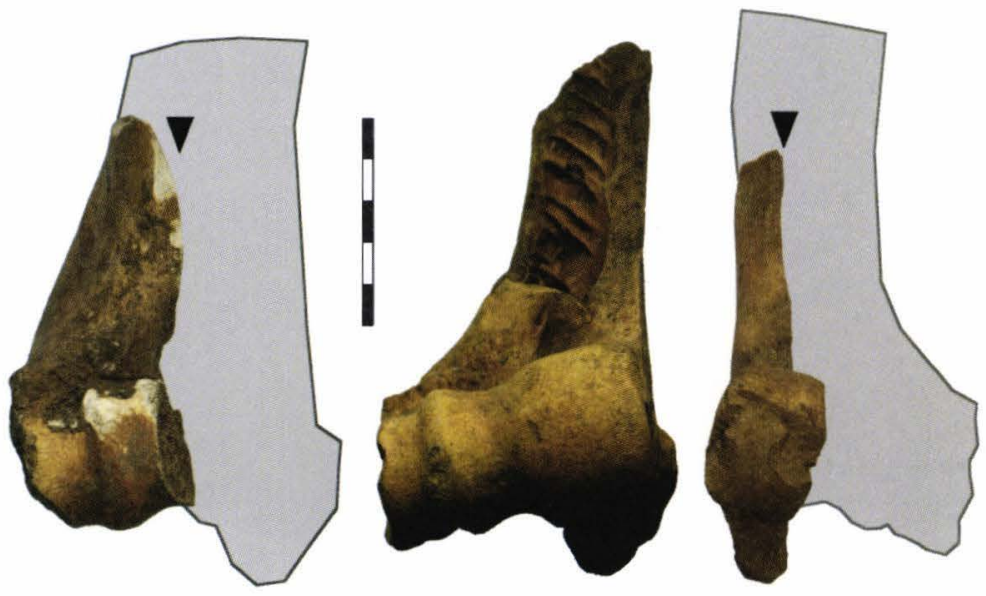

5.

1. Neurocraniu de vită (Bos taururs) acornut; 2. Coxal stâng de vită (Bos taurus) cu urme de tăiere la nivelul articulației acetabulare; 3. Scapulă de vită (Bos taurus) cu urme de spargere longitudinală pe capul scapular (stânga), detaliu (dreapta); 4. Humerusuri de vită (Bos taurus) cu urme de spargere longitudinală (vedere cranială) 


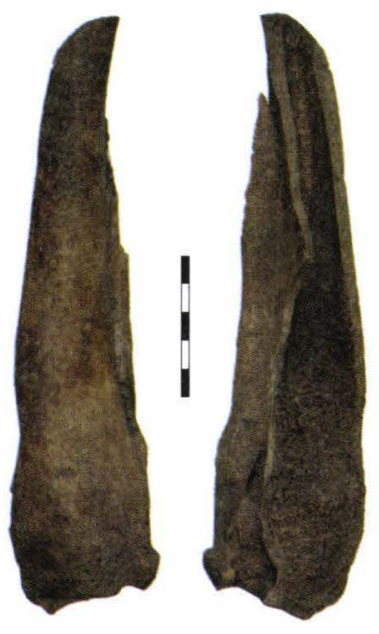

1.

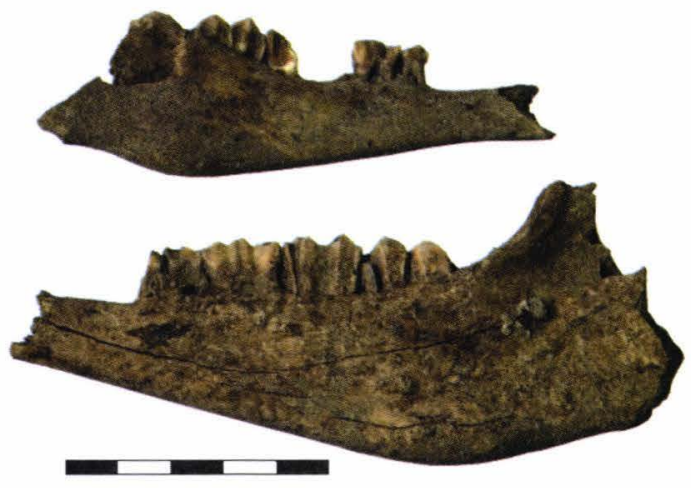

4.

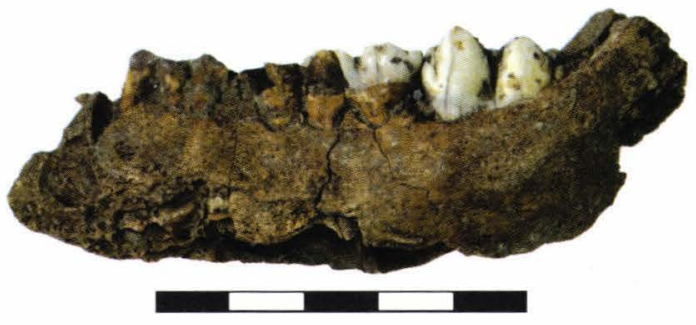

6.

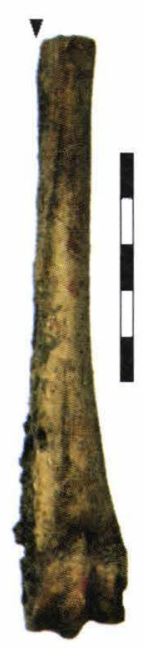

2.

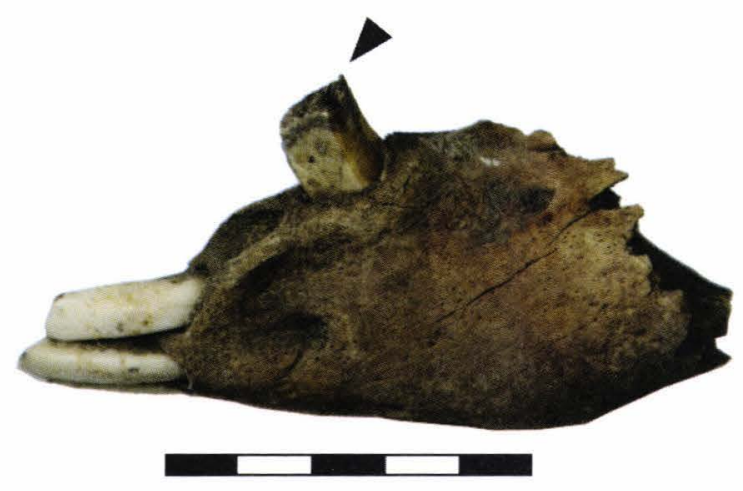

5.

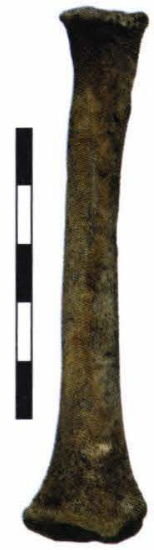

7.

1. Radius de vită (Bos taururs) cu urme de spargere longitudinală (vedere dorsală ți palmară); 2. Metatars de vită (Bos taururs) cu urme de spargere longitudinală; 3. Proces cornular de capră (Capra hircus); 4. Mandibule de oaie (Ovis aries); 5. Mandibule de porc mascul (Sus domesticus) cu zona incisivilor ți a caninului care prezintă urme de ardere; 6. Manidbulă de porc (Sus domesticus); 7. Radius de bursuc (Meles meles) 